\title{
Human health effects of conjugated linoleic acid from milk and supplements
}

\author{
Tracy A. McCrorie ${ }^{1 *}$, Edel M. Keaveney ${ }^{1}$, Julie M. W. Wallace ${ }^{1}$, Nino Binns ${ }^{2}$ and \\ M. Barbara E. Livingstone ${ }^{1}$ \\ ${ }^{1}$ Northern Ireland Centre for Food and Health (NICHE), University of Ulster, Cromore Road, Coleraine, County Londonderry \\ BT52 1SA, UK \\ ${ }^{2}$ Nino Binns Consulting, Grange Rath, Drogheda, County Louth, Republic of Ireland
}

\begin{abstract}
The primary purpose of the present review was to determine if the scientific evidence available for potential human health benefits of conjugated linoleic acid (CLA) is sufficient to support health claims on foods based on milk naturally enriched with cis-9, trans-11-CLA $(c 9, t 11$-CLA). A search of the scientific literature was conducted and showed that almost all the promising research results that have emerged in relation to cancer, heart health, obesity, diabetes and bone health have been in animal models or in vitro. Most human intervention studies have utilised synthetic CLA supplements, usually a 50:50 blend of $c 9, t 11$-CLA and trans-10, cis-12-CLA ( $t 10, c 12$-CLA). Of these studies, the only evidence that is broadly consistent is an effect on body fat and weight reduction. A previous review of the relevant studies found that $3.2 \mathrm{~g} \mathrm{CLA} / \mathrm{d}$ resulted in a modest body fat loss in human subjects of about $0.09 \mathrm{~kg} /$ week, but this effect was attributed to the $t 10, c 12$-CLA isomer. There is no evidence of a consistent benefit of $c 9, t 11$-CLA on any health conditions; and in fact both synthetic isomers, particularly $t 10, c 12$-CLA, have been suspected of having pro-diabetic effects in individuals who are already at risk of developing diabetes. Four published intervention studies using naturally enriched CLA products were identified; however, the results were inconclusive. This may be partly due to the differences in the concentration of CLA administered in animal and human studies. In conclusion, further substantiation of the scientific evidence relating to CLA and human health benefits are required before health claims can be confirmed.
\end{abstract}

Key words: Conjugated linoleic acid: Cis-9, trans-11-conjugated linoleic acid: Milk

\section{Introduction}

The primary purpose of the present review was to determine if the level of scientific evidence available for potential human health benefits of conjugated linoleic acid (CLA) is sufficient to support health claims on foods based on naturally CLA-enriched milk. Health claims on foods in Europe must now be selected from community lists of approved claims or be the subject of a scientific dossier to gain approval ${ }^{(1)}$. In order to gain approval, the scientific evidence must be based on human studies, with human intervention studies accorded a higher weighting ${ }^{(1)}$. Cows' milk contains predominantly the cis-9, trans- 11 isomer of CLA ( $c 9, t 11$-CLA). Naturally CLA-enriched milk is defined for the purpose of the present review as milk obtained from grass-feeding regimens that have proven to result in higher levels of $c 9, t 11$-CLA than do conventional feeding regimens (see below).

'Conjugated linoleic acid' is a term used to describe a mixture of positional and geometric isomers of linoleic acid containing conjugated double bonds. It is a group of naturally occurring fatty acids synthesised as intermediates in the biohydrogenation of linoleic and linolenic acid in the rumen of animals, and thus is predominantly found in dairy products and ruminant meat ${ }^{(2)}$. It can also be synthesised by industrial partial hydrogenation or alkali-isomerisation of linoleic $\operatorname{acid}^{(3)}$. CLA includes twenty-eight possible isomers, with two of these - cis-9, trans-11-CLA (c9,t11-CLA) and trans-10, cis-12-CLA (t10,c12-CLA) being known to possess biological activity ${ }^{(4)}$. Commercially available CLA supplements usually contain $c 9, t 11$ CLA and $t 10, c 12$-CLA at a ratio of approximately $1: 1$. The majority of CLA in the human diet occurs as $c 9, t 11$-CLA, with this isomer accounting for $85-90 \%$ of the total CLA content in dairy products ${ }^{(5)}$.

CLA was first discovered in 1932, by scientists at the University of Reading (UK) who were investigating seasonal variation in the vitamin content of milk ${ }^{(6)}$. Interest in the potential health benefits of CLA was later sparked by the

Abbreviations: BFM, body fat mass; CLA, conjugated linoleic acid; CRP, C-reactive protein; $c 9, t 11$-CLA, cis-9, trans-11-conjugated linoleic acid; LBM, lean body mass; $t 10, c 12$-CLA, trans-10, cis-12-conjugated linoleic acid; UHT, ultra-high temperature.

*Corresponding author: Dr Tracy McCrorie, fax +44 287032 3023, email t.mccrorie@ulster.ac.uk 
identification of CLA's anti-carcinogenic activity in vitro, in extracts from fried ground beef ${ }^{(7)}$. Since then, numerous studies and reviews have investigated the potential health benefits of CLA, with purported health benefits including anti-cancer, anti-atherogenic, anti-adipogenic, anti-diabetogenic, anti-inflammatory and effects on bone health, at least in vitro.

CLA is present in relatively low quantities (mg) in meat and dairy products ${ }^{(2)}$. Estimated dietary intakes from $3 \mathrm{~d}$ diet records in the USA are $176 \mathrm{mg}$ total CLA per $\mathrm{d}$ for men, with slightly lower intakes for women $(104 \mathrm{mg} / \mathrm{d})$. However, in the UK, intake of $c 9, t 11$-CLA was estimated to be $97.5 \mathrm{mg} / \mathrm{d}^{(8)}$. Furthermore, this may vary depending on the method used to assess dietary intake ${ }^{(9)}$. In recent times, there has been a surge of interest in increasing the concentration of CLA in food in order to increase dietary CLA intake. Cows' milk fat is the richest natural source of $\mathrm{CLA}^{(10)}$; therefore, interest has focused on the potential for naturally increasing the $c 9, t 11$-CLA content of milk and dairy products. Levels of CLA in milk fat ranging from 2 to $37 \mathrm{mg} / \mathrm{g}$ fat have been recorded and are due to numerous factors ${ }^{(11)}$. The composition of the animals' diet is a major factor, with cows that graze on fresh pasture having higher concentrations of CLA in their milk fat than those grazing on hay or concentrates ${ }^{(12)}$. However, cows that are fed the same diet can demonstrate large intraindividual variation in CLA levels, which may be due to differences in metabolism and the rumen microflora responsible for biohydrogenation ${ }^{(10)}$. Altitude, breed and lactation age can also influence CLA levels ${ }^{(10)}$. Research in the UK has shown that there is no difference between the content of CLA in milk from organic and conventional farms ${ }^{(13)}$. Furthermore, it appears that processing of dairy products causes insignificant changes in CLA levels, particularly compared with the large variations in CLA levels due to diet and intra-individual variation ${ }^{(10)}$.

Much research has been carried out on strategies to manipulate the diets of cows to produce CLA-rich milk, which can then be used to make CLA-rich dairy products. Supplementing the diets of cows with plant oils rich in linoleic or linolenic acid (such as sunflower-seed, soyabean or linseed oil) is known to cause an increase in the concentration of $c 9, t 11$-CLA in milk fat ${ }^{(14)}$. A study which evaluated the characteristics of naturally CLA-enriched ultra-high temperature (UHT) milk, butter and cheese reported that although the sensory profiles of the CLAenriched products were different from those of control products, subjects did not rate the overall impression and flavour as being different ${ }^{(15)}$. It has also been shown that consumption of naturally CLA-enriched dairy products for 6 weeks, at similar levels to which conventional dairy products are habitually consumed in the UK, increases $c 9, t 11$ CLA concentration in plasma lipids ${ }^{(16)}$. Together these data show that it is feasible and acceptable to increase $c 9, t 11$ CLA intake in the human diet by producing naturally CLA-enriched dairy products for consumption.

\section{Methods}

The overall purpose of the present review was to examine the current literature in relation to $c 9, t 11$-CLA and human health benefits with the focus on, in particular, milk and dairy products where CLA content has been enhanced by natural feeding regimens. As there are relatively few studies on enhanced dairy products and in order to identify potential opportunities for future research on $c 9, t 11$-CLA, studies on synthetic CLA isomers were also considered but not subject to exhaustive review. Much of the interest in CLA has been provoked by promising results from animal and in vitro studies and in order to put this in context, an overview of these studies is provided although this does not represent a complete picture of the large body of literature.

Initially, reviews were identified from PubMed and used to provide an overview of the key areas of interest. Subsequently, Medline, Embase and evidence-based medicine (EBM) reviews (including Cochrane) were searched via OvidSP (Wolters Kluwer, Alphen aan den Rijn, The Netherlands) using the terms 'CLA', 'conjugated linoleic acid' and 'dairy', both separately and together. Thus, for all databases, this yielded:

(a) 535 for 'CLA' (subheading: 'conjugated linoleic acid');

(b) 41760 for 'dairy' (subheadings: 'dairy products' and 'milk');

(c) Combining both searches above yielded fifty-six papers;

(d) Separate searches with the above databases for ' $c i s-9$, trans-11' yielded 13525 papers;

(e) Medline was searched for 'cis-9, trans-11'; only 4476 papers were found and the introduction of 'human' reduced the number of papers to 1378. Further specification to linoleic acids, conjugated yielded 348;

(f) Embase ( $n$ 9002) - narrowed to 'humans' and 'CLA' (n 120);

(g) EBM reviews ( $n$ 37) - narrowed to 'humans' and 'CLA' ( $n$ 35).

The searches were merged using a reference manager programme and duplicates removed, with a total of 538, the abstracts were then examined to determine whether the studies were relevant to the present review. A total of sixty-six human studies utilising observational, randomised control trials and crossover designs, published up to July 2011, were included in the present review. References within studies were also checked for completeness. Reviews on animal studies were identified to provide an overview and then key references followed up individually.

\section{Conjugated linoleic acid and cancer}

Since the initial identification of CLA from grilled minced beef and its anticarcinogenic effects on skin cancer 
tumours in mice ${ }^{(7)}$, the intervening years have provided a cascade of studies and reviews examining the anticarcinogenic properties of CLA. The mechanisms relating to anticarcinogenic properties of CLA are largely unresolved; CLA may act by antioxidant mechanisms, pro-oxidant cytotoxicity, inhibition of nucleotide and protein synthesis, reduction of cell proliferative activity and inhibition of both DNA-adduct formation and carcinogen activation ${ }^{(17-19)}$. The studies examined in these reviews have identified potential beneficial effects of CLA on colorectal, breast and prostate cancer, with the majority of evidence from animal and in vitro studies.

CLA has shown consistent anticarcinogenic effects against several types of experimental cancer ${ }^{(20)}$ including breast cancer ${ }^{(21,22)}$. A review by Kelley et al. ${ }^{(19)}$ examined the literature in terms of the effects of studies where purified isomers of CLA were administered. Results from in vitro studies suggest that the effects of the two isomers of CLA vary according to the cancer model examined. In the majority of studies, c9,t11-CLA did not inhibit tumour growth, whereas $t 10, c 12$-CLA demonstrated inhibitory effects in studies using mouse and human mammary tumour cell lines. The $t 10, c 12$-CLA isomer also inhibited cell growth in colon and gastric cancer cell lines. However, c9,t11-CLA was more potent than t10,c12-CLA in colon cell lines where both isomers were examined, though the optimal concentration level varied between studies $(50 \mu \mathrm{mol} / \mathrm{l}$ and $200 \mu \mathrm{mol} / \mathrm{l})^{(23,24)}$. Subsequent work by Yasui et al. ${ }^{(25)}$ also confirmed the chemopreventive effect of $c 9, t 11$-CLA against pre-initiation (dose-dependent) as well as post-initiation stages of colorectal carcinogenesis (doses $\leq 1 \%$ of diet).

Overall, in studies using animal models of cancer, the purified $c 9, t 11$-CLA isomer reduced tumorigenesis in six studies and showed no effect in two others ${ }^{(19)}$. Similarly, the $t 10, c 12$-CLA isomer decreased tumorigenesis in six studies, but in contrast increased tumorigenesis in two studies. Interestingly, three studies included in the present review found similar effects on the reduction of mammary tumours when a naturally enriched butter ${ }^{(26)}$ and synthetic isomers of $c 9, t 11$-CLA were fed to rats ${ }^{(27)}$ and mice ${ }^{(28)}$. Though more recent work suggests that $t 10, c 12$-CLA stimulates mammary tumours in a mouse model, where the gene erbB2/her2 is over-expressed, application of c9,t11-CLA showed no apparent effects ${ }^{(29)}$. The same paper also demonstrated that the reduction in tumours was in the same order of magnitude irrespective of whether the CLA source was natural or synthetic. The authors of this paper suggest that it would be prudent to avoid supplements containing $t 10, c 12$-CLA in those at risk of developing breast cancer in which the erbB2/her 2 gene is overexpressed (observed in $20-30 \%$ of human breast cancers), whereas supplements containing $c 9, t 11$-CLA may be safe and efficacious in breast cancer prevention ${ }^{(29)}$. However, due to the differences in proliferation of tumours by the site of cancer, combining results may not elicit the true effects of CLA as an anti-carcinogenic agent, though in vitro and animal studies do demonstrate potential benefits.

The manifestation of cancer is not a practical end-point in human studies, combined with the numerous genetic and environmental risk factors for different cancers. Consequently, the majority of studies relating to CLA and cancer in humans are observational studies, particularly on breast cancer (Table 1). Dietary and serum CLA was shown to be significantly lower in postmenopausal cases of breast cancer compared with controls, thus suggesting a protective effect of CLA ${ }^{(30)}$. In a continuation of this study, breast adipose concentrations of CLA were not significantly different between cases and controls ${ }^{(31)}$. Furthermore, there was no association between breast adipose tissue CLA concentration and prognostic factors of breast cancer or occurrence of metastases during a 7.5 -year follow-up period ${ }^{(32)}$. In the Netherlands Cohort Study on Diet and Cancer, intake of milk and milk products and meat products, as major sources of dietary CLA, showed no relationship with breast cancer incidence in postmenopausal patients ${ }^{(33)}$. This could be attributed to the fact that there were no significant differences in total CLA intake between cancer cases and controls ${ }^{(33)}$. The null association between breast cancer risk and intake of CLA was also demonstrated in a large epidemiological study in Sweden ${ }^{(34)}$. In contrast, in the same cohort, women who consumed four or more servings of high-fat dairy foods per d (including whole milk, full-fat cultured milk, cheese, cream, soured cream and butter) had a lower risk of developing colorectal cancer ${ }^{(35)}$. It has been suggested that a higher intake of $c 9, t 11$-CLA confers a reduced risk of a specific type of breast cancer tumour in premenopausal women. However, further investigation is warranted, as the sample size was small ${ }^{(36)}$.

Recently, one small cross-over study examined colon cancer markers after subjects ( $n$ 15) consumed milk naturally enriched with $c 9, t 11$-CLA or synthetically enriched with $t 10, c 12$-CLA or normal milk as a control ${ }^{(37)}$. There were large variations in the responses to supplementation across all three groups (NS), therefore all data were combined and a significant decrease in enzyme activity $\beta$-glucosidase, nitroreductase and urease; $P<0.01$ between day 0 and day 56 was observed. The authors stated that this was important due to links between enzymic activity and the production of carcinogens. However, it is important to note that the main aim of the study was to examine the effects of CLA-enriched milk on lipid metabolism and body composition ${ }^{(38)}$.

Currently the evidence for the anti-carcinogenic properties of CLA in human subjects is limited to observational studies, with broader epidemiological evidence not specifically focusing on CLA but rather on milk and dairy products. The World Cancer Research Fund \& Association for International Cancer Research report reviewed the available evidence on the consumption of milk and links with cancer ${ }^{(39)}$. The report concluded that milk probably protects against colorectal cancer, whereas there is limited 
Table 1. Effect of conjugated linoleic acid (CLA) on cancer in human subjects

\begin{tabular}{|c|c|c|c|c|}
\hline Reference & $\begin{array}{l}\text { Outcomes } \\
\text { examined }\end{array}$ & Number of subjects & Design & Overall result \\
\hline $\begin{array}{l}\text { Aro et al. } \\
\qquad(2000)^{(30)}\end{array}$ & Cancer (breast) & $\begin{array}{l}195 \text { Cases; } \\
208 \text { controls, F }\end{array}$ & $\begin{array}{l}\text { Case-control study. } \\
\text { Dietary intake of } \\
\text { CLA from FFQ }\end{array}$ & $\begin{array}{l}\text { Postmenopausal women who consumed } \\
\text { the lowest levels of CLA had a } \\
\text { 3.3-fold greater risk of breast cancer } \\
\text { than women who consumed the highest levels }\end{array}$ \\
\hline $\begin{array}{l}\text { Chajes et al. } \\
\qquad(2002)^{(31)}\end{array}$ & Cancer (breast) & $\begin{array}{l}\text { Cases } 241 \mathrm{~F} \\
\text { controls } 88 \mathrm{~F}\end{array}$ & $\begin{array}{l}\text { Case-control study. } \\
\text { CLA content of breast } \\
\text { adipose tissue }\end{array}$ & $\begin{array}{l}\text { No association between CLA in breast } \\
\text { adipose tissue and breast cancer risk }\end{array}$ \\
\hline $\begin{array}{l}\text { Voorrips et al. } \\
\qquad(2002)^{(33)}\end{array}$ & Cancer (breast) & $\begin{array}{l}941 \text { Cancer cases, } \\
1598 \text { cancer-free } \\
\text { subjects }\end{array}$ & $\begin{array}{l}\text { Prospective study, } \\
\text { 6.4-year follow-up. } \\
\text { Dietary CLA from FFQ }\end{array}$ & $\begin{array}{l}\text { No evidence of a protective effect of higher } \\
\text { CLA intake on breast cancer incidence } \\
\text { in postmenopausal women }\end{array}$ \\
\hline $\begin{array}{l}\text { Chajes et al. } \\
\qquad(2003)^{(32)}\end{array}$ & Cancer (breast) & $209 \mathrm{~F}$ & $\begin{array}{l}\text { Prospective study, } \\
\text { 7.5-year follow-up. } \\
\text { CLA content of breast } \\
\text { adipose tissue }\end{array}$ & $\begin{array}{l}\text { No association between CLA in breast adipose } \\
\text { tissue and breast cancer risk or death }\end{array}$ \\
\hline $\begin{array}{l}\text { McCann et al. } \\
\qquad(2004)^{(36)}\end{array}$ & Cancer (breast) & $\begin{array}{l}\text { Cases } 1122 \mathrm{~F} ; \\
\text { controls } 2036 \mathrm{~F}\end{array}$ & $\begin{array}{l}\text { Case-control study. } \\
\text { Dietary intake of CLA } \\
\text { and } c 9, t 11-C L A \text { from FFQ }\end{array}$ & $\begin{array}{l}\text { Very little association between CLA intakes } \\
\text { and breast cancer. However, relationship } \\
\text { between } c 9, t 11 \text { intake and premenopausal. } \\
\text { women - reduced risk of ER-negative tumours }\end{array}$ \\
\hline $\begin{array}{l}\text { Larsson et al. } \\
\qquad(2005)^{(35)}\end{array}$ & Cancer (colon) & $60708 \mathrm{~F}$ & $\begin{array}{l}\text { Prospective study, } \\
\text { 14.8-year follow-up. } \\
\text { Dietary intake } \\
\text { of CLA from FFQ }\end{array}$ & $\begin{array}{l}\text { Highest intake of CLA ( }>149 \mathrm{mg} / \mathrm{d}) 29 \% \text { less } \\
\text { likely to develop colorectal cancer compared } \\
\text { with women with low intakes }(<73.4 \mathrm{mg} / \mathrm{d})\end{array}$ \\
\hline $\begin{array}{l}\text { Farnworth et al. } \\
\qquad(2007)^{(37)}\end{array}$ & Cancer (colon) & $15 \mathrm{M}+\mathrm{F}$ & $\begin{array}{l}\text { RCT, } 8 \text { weeks, cross-over. } \\
\text { Daily, } 1 \text { litre of control } \\
\text { milk ( } 5 \mathrm{mg} / \mathrm{g}) \text {; naturally } \\
\text { enriched milk } \\
\text { ( } 32 \mathrm{mg} c 9, t 11-C L A / d) ; \\
\text { synthetically enriched } \\
\text { ( } t 10, c 12-C L A \text { and } \\
c 9, t 11-C L A 32 \mathrm{mg} / \mathrm{g} \text { fat) }\end{array}$ & $\begin{array}{l}\text { Inconclusive evidence but reductions in faecal } \\
\text { enzyme activity evident, but not attributable } \\
\text { to changes in the population of one or } \\
\text { more faecal bacteria - long-term effects } \\
\text { of reducing these enzymes may be desirable }\end{array}$ \\
\hline $\begin{array}{l}\text { Larsson et al. } \\
\qquad(2009)^{(34)}\end{array}$ & Cancer (breast) & $61 \mathrm{M}, 433 \mathrm{~F}$ & $\begin{array}{l}\text { Prospective study, } \\
\text { 17.4-year follow-up; } \\
\text { dietary intake from FFQ }\end{array}$ & $\begin{array}{l}\text { No evidence of protective effect of CLA on } \\
\text { breast cancer development }\end{array}$ \\
\hline
\end{tabular}

$\mathrm{F}$, female; c9,t11, cis-9, trans-11; ER, oestrogen receptor; M, male; RCT, randomised controlled trial; t10,c12, trans-10, cis-12.

evidence suggesting that cheese is a cause of colorectal cancer. There is also limited evidence suggesting that consumption of milk conveys a protective effect against bladder cancer. In contrast, diets high in $\mathrm{Ca}$ are a probable cause of prostate cancer, but there is limited evidence suggesting that high consumption of milk and dairy products is a cause of prostate cancer ${ }^{(39)}$. Currently the evidence available is confusing, with suggestions that the effects are dependent on the site of the cancer due to the complex nature of diet, environment and nutrient interactions. However, a substantial amount of further work is required to fully elucidate the potential anti-carcinogenic properties of CLA in humans.

\section{Conjugated linoleic acid and body composition}

The overwhelming increases in the proportion of overweight and obesity in the world have been the focus of much debate and research. Currently two-thirds of the UK adult population are classified as overweight or obese (BMI $\left.>25 \mathrm{~kg} / \mathrm{m}^{2}\right)^{(40)}$. Obesity is a multifaceted disorder, largely driven by its co-morbidities including type 2 diabetes, insulin resistance and CVD. To date feasible and sustainable approaches to prevent further increases in overweight and obesity, let alone attenuate it, have remained largely elusive. More recently, obesity has been recognised as a state of chronic or low-grade systemic inflammation, due to the abnormal circulating levels of inflammatory molecules, including TNF $\alpha$, leptin and IL-6, which are secreted by adipose tissue ${ }^{(41)}$.

Studies in animals have shown that feeding CLA at levels of $0.5-1 \%$ of the diet reduces body fat in mice, chickens, hamsters, rats and pigs ${ }^{(42)}$. The most substantial decreases in body fat have been observed in mice, where CLA at levels of $0.5 \%$ of the diet has been shown to lower body fat by 40 to $80 \%{ }^{(42)}$. This effect is thought to be attributable to the $t 10, c 12$-CLA isomer, as the greatest body fat reductions in mice were observed with a CLA mix with a higher proportion of $t 10, c 12-$ CLA than $c 9, t 11-$ CLA $^{(43)}$. Also, in vitro, t10,c12-CLA prohibits TAG accumulation in cultures of differentiating human preadipocytes, whereas c9,t11-CLA increases TAG content ${ }^{(43)}$. Evidence suggests that this effect may be due in part to a reduction in lipid uptake by adipocytes due to effects of CLA on stearoylCoA desaturase and lipoprotein lipase activity ${ }^{(4)}$.

Promising evidence from animal studies led to an array of human intervention studies being carried out investigating the effect of CLA on body composition in normal 
weight, overweight and obese subjects. The majority of these studies used a 50:50 (c9,t11-CLA and t10,c12-CLA) CLA mix, and results have been inconsistent. Almost all of these studies have shown no effect on body weight; however, some have reported reduced body fat mass (BFM) following supplementation with CLA, as discussed in detail below.

The body composition studies conducted in normalweight adults (Table 2) have supplemented with 0.7-5.5 g 50:50 CLA/d, for 4-16 weeks, and of those which measured BFM, some have reported non-significant changes $^{(44,46,47,50,79,175)}$, and others have reported BFM reductions of $4 \%$ up to $20 \%{ }^{(51-56)}$. However, it is important to note that in some of the studies that have reported significant BFM reductions in normal-weight adults, subjects were involved in physical training throughout the supplementation periods, which may potentially be a confounder ${ }^{(53-55)}$.

In overweight and obese human subjects (Table 3), 50:50 CLA given at doses of $1.7-6.8 \mathrm{~g} / \mathrm{d}$, over periods of 4 to 104 weeks, has resulted in non-significant BFM changes in some instances ${ }^{(57-63)}$, and reductions of $3-15 \%$ in other studies ${ }^{(50,57-63,77,78)}$. The greatest reduction in BFM (14.8\%) was observed in a study of patients on blood pressure-lowering medication, who were supplemented with $4.5 \mathrm{~g}$ 50:50 CLA/d for 8 weeks ${ }^{(71)}$. In apparently healthy adults, the greatest reduction in BFM (6\%) was observed in the study by Gaullier et al. ${ }^{(6)}$

Table 2. Effect of conjugated linoleic acid (CLA) on body composition in normal-weight human subjects

\begin{tabular}{|c|c|c|c|c|}
\hline Reference & Form of CLA & Number of subjects & Design & Overall result \\
\hline $\begin{array}{l}\text { Thom et al. } \\
\qquad(2001)^{(53) *}\end{array}$ & CLA mixture & $10 \mathrm{M}, 10 \mathrm{~F}$ & $\begin{array}{l}\mathrm{RCT}, 12 \text { weeks, } \\
1.8 \mathrm{~g} \text { CLA } / \mathrm{d}\end{array}$ & $\begin{array}{l}\text { No significant change in } \\
\text { body weight. Significant decrease } \\
\text { in BFM }(20 \%)\end{array}$ \\
\hline $\begin{array}{l}\text { Mougios \& } \\
\text { Vessby }(2001)^{(51)}\end{array}$ & CLA mixture & $13 \mathrm{M}, 9 \mathrm{~F}$ & $\begin{array}{l}8 \text { weeks, } 0.7 \mathrm{~g} \\
\text { CLA/d for weeks } 1-4 \text {, } \\
1.4 \mathrm{~g} \mathrm{CLA} / \mathrm{d} \text { for } \\
\text { weeks } 5-8\end{array}$ & $\begin{array}{l}\text { No significant change in body weight. } \\
\text { Significant decrease in } \\
\text { BFM (skinfolds) with } 1.4 \mathrm{~g} \text { CLA }\end{array}$ \\
\hline $\begin{array}{l}\text { Smedman et al. } \\
(2001)^{(52)}\end{array}$ & CLA mixture & $80 M+F$ & $\begin{array}{l}\mathrm{RCT}, 12 \text { weeks, } \\
4.2 \mathrm{~g} \mathrm{CLA} / \mathrm{d}\end{array}$ & $\begin{array}{l}\text { No significant change in body weight. } \\
\text { Significant decrease in BFM (4\%) }\end{array}$ \\
\hline $\begin{array}{l}\text { Noone et al. } \\
\qquad(2002)^{(106)}\end{array}$ & $\begin{array}{l}\text { CLA mixture or } 80: 20 c 9, t 11 \\
\text { and } t 10, c 12-C L A\end{array}$ & $18 \mathrm{M}, 33 \mathrm{~F}$ & $\begin{array}{l}8 \text { weeks, } 3 \text { g } 50: 50 \text { CLA/d } \\
\text { or } 3 \mathrm{~g} 80: 20 \mathrm{CLA} / \mathrm{d}\end{array}$ & $\begin{array}{l}\text { No significant change in body weight. } \\
\text { BFM not determined }\end{array}$ \\
\hline $\begin{array}{l}\text { Kreider et al. } \\
(2002)^{(175)}\end{array}$ & CLA mixture (Tonalin) & $23 \mathrm{M}$ & $\begin{array}{l}\text { RCT, with resistance } \\
\text { training, } 28 \mathrm{~d} \text {, } \\
6 \mathrm{~g} \mathrm{CLA} \text { mixture/d }\end{array}$ & $\begin{array}{l}\text { No significant change in body weight } \\
\text { or BFM }\end{array}$ \\
\hline $\begin{array}{l}\text { Belury et al. } \\
\qquad(2003)^{(74)}\end{array}$ & CLA mixture & $21 M+F$ & 8 weeks, $6 \mathrm{~g} \mathrm{CLA} / \mathrm{d}$ & $\begin{array}{l}\text { No significant change in body weight. } \\
\text { BFM not determined }\end{array}$ \\
\hline $\begin{array}{l}\text { Petridou et al. } \\
\qquad(2003)^{(44)}\end{array}$ & CLA mixture & $16 \mathrm{~F}$ & RCT, 6 weeks, $2.1 \mathrm{~g} \mathrm{CLA} / \mathrm{d}$ & $\begin{array}{l}\text { No significant change in body weight } \\
\text { or BFM }\end{array}$ \\
\hline $\begin{array}{l}\text { Tricon et al. } \\
\qquad(2004)^{(79)}\end{array}$ & $c 9, t 11-$ or $t 10, c 12-\mathrm{CLA}$ & $39-49 \mathrm{M}$ & $\begin{array}{l}\text { RCT, cross-over, } 8 \text { weeks, } \\
0.59,1.19 \text { or } 2.38 \mathrm{~g} \\
c 9, t 11-\mathrm{CLA} / \mathrm{d} \text { or } 0.6 \\
1.3 \text { or } 2.5 \mathrm{~g} t 10, c 12-\mathrm{CLA} / \mathrm{d}\end{array}$ & $\begin{array}{l}\text { No significant change in body weight } \\
\text { or BFM }\end{array}$ \\
\hline $\begin{array}{l}\text { Tricon et al. } \\
\quad(2006)^{(45)}\end{array}$ & $\begin{array}{l}\text { Supplemented cows' } \\
\text { diets to produce milk } \\
\text { naturally enriched } \\
\text { with } c 9, t 11-C L A \text { to } \\
\text { make products }\end{array}$ & $32 \mathrm{M}$ & $\begin{array}{l}\text { RCT, cross-over, } 6 \text { weeks, } \\
0.15 \text { or } 1.42 \mathrm{~g} \mathrm{c} 9, t 11-\mathrm{CLA} / \mathrm{d}\end{array}$ & $\begin{array}{l}\text { No significant change in body weight. } \\
\text { BFM not determined }\end{array}$ \\
\hline $\begin{array}{l}\text { Colakoglu et al. } \\
\qquad(2006)^{(54) \star}\end{array}$ & CLA mixture & $44 \mathrm{~F}$ & $\mathrm{RCT}, 6$ weeks, $3.6 \mathrm{~g} \mathrm{CLA} / \mathrm{d}$ & $\begin{array}{l}\text { No significant change in body weight. } \\
\text { Significant decrease in BFM (8\%) }\end{array}$ \\
\hline $\begin{array}{l}\text { Pinkoski et al. } \\
\qquad(2006)^{(55)_{\star}}\end{array}$ & CLA mixture & $42 \mathrm{M}, 43 \mathrm{~F}$ & $\mathrm{RCT}, 7$ weeks, $5 \mathrm{~g} \mathrm{CLA} / \mathrm{d}$ & $\begin{array}{l}\text { No significant change in body weight. } \\
\text { Significant decrease in BFM (4\%) }\end{array}$ \\
\hline $\begin{array}{l}\text { Lambert et al. } \\
\qquad(2007)^{(46)}\end{array}$ & CLA mixture & $62 M+F$ & RCT, 12 weeks, $3.9 \mathrm{~g} \mathrm{CLA} / \mathrm{d}$ & $\begin{array}{l}\text { No significant change in body weight } \\
\text { or BFM }\end{array}$ \\
\hline $\begin{array}{l}\text { Nazare et al. } \\
\quad(2007)^{(47)}\end{array}$ & $\begin{array}{l}\text { CLA mixture, } \\
\text { added to yoghurt }\end{array}$ & $44 \mathrm{M}+\mathrm{F}$ & RCT, 14 weeks, $3.8 \mathrm{~g} \mathrm{CLA} / \mathrm{d}$ & $\begin{array}{l}\text { No significant change in body } \\
\text { weight or BFM }\end{array}$ \\
\hline $\begin{array}{l}\text { Raff et al. } \\
\qquad(2009)^{(56)}\end{array}$ & $\begin{array}{l}\text { CLA mixture } \\
\text { or } c 9, t 11-C L A\end{array}$ & $75 \mathrm{~F}$ & $\begin{array}{l}\text { RCT, } 16 \text { weeks, } 5.5 \mathrm{~g} \text { CLA/d or } \\
5.5 \mathrm{~g} \mathrm{c} 9, t 11-\mathrm{CLA} / \mathrm{d}\end{array}$ & $\begin{array}{l}\text { Significant decrease in BFM (4\%) } \\
\text { and lower-body fat mass (7\%) } \\
\text { with CLA mixture }\end{array}$ \\
\hline $\begin{array}{l}\text { Wanders et al. } \\
\qquad(2010)^{(49)}\end{array}$ & $\begin{array}{l}\text { Foods enriched with } \\
\text { CLA-rich oil, } 7 \% \text { of } \\
\text { total energy as CLA } \\
(78 \% \text { c9,t11-CLA and } \\
17 \% t 10, c 12-C L A)\end{array}$ & $25 \mathrm{M}, 36 \mathrm{~F}$ & $\begin{array}{l}\text { RCT, crossover, } 21 \mathrm{~d} \text {, oleic } \\
\text { (control) or industrial } \\
\text { trans-fatty acids or } 26.8 \mathrm{~g} \\
\text { CLA isomers } / \mathrm{d}\end{array}$ & $\begin{array}{l}\text { No significant changes in body weight } \\
\text { between diets }\end{array}$ \\
\hline $\begin{array}{l}\text { Brown et al. } \\
\qquad(2011)^{(50)}\end{array}$ & $\begin{array}{l}\text { Beef and dairy products } \\
\text { rich in CLA from } \\
\text { pasture-fed dairy cattle }\end{array}$ & $18 \mathrm{~F}$ & $\mathrm{RCT}, 56 \mathrm{~d}, 1.17 \mathrm{~g} \mathrm{CLA} / \mathrm{d}$ & $\begin{array}{l}\text { No significant changes in body weight, } \\
\text { BFM or LBM }\end{array}$ \\
\hline
\end{tabular}

CLA mixture, 50:50 cis-9, trans-11- and trans-10, cis-12-CLA; M, male; F, female; RCT, randomised controlled trial; BFM, body fat mass; c9,t11, cis-9, trans-11; t10,c12, trans-10, cis-12; LBM, lean body mass.

* Subjects exercising. 
WS Nutrition Research Reviews

Table 3. Effect of conjugated linoleic acid (CLA) on body weight or body composition in overweight and obese human subjects

\begin{tabular}{|c|c|c|c|c|}
\hline Reference & Form of CLA & Number of subjects & Design & Overall result \\
\hline Berven et al. $(2000)^{(59)}$ & CLA mixture & $17 \mathrm{~F}, 30 \mathrm{M}$ & $\mathrm{RCT}, 12$ weeks, $3.44 \mathrm{~g}$ CLA $/ \mathrm{d}$ & No significant change in body weight or BFM \\
\hline Blankson et al. $(2000)^{(64)}$ & CLA mixture & $47 M+F$ & $\begin{array}{l}\text { RCT, } 12 \text { weeks, } 1.7,3.4,5.1 \\
\quad \text { or } 6.8 \mathrm{~g} \mathrm{CLA} / \mathrm{d}\end{array}$ & $\begin{array}{l}\text { No significant changes in body composition } \\
\text { between groups. Significant reduction in BFM } \\
\text { within } 3.4 \text { and } 6.8 \mathrm{~g} / \mathrm{d} \text { groups }(6 \%) \text {, no additional } \\
\text { effect with } 6.8 \mathrm{~g} / \mathrm{d} \text { over that seen with } 3.4 \mathrm{~g} / \mathrm{d}\end{array}$ \\
\hline Risérus et al. (2001) ${ }^{(101)}$ & CLA mixture & $24 \mathrm{M}$ & $\mathrm{RCT}, 4$ weeks, $4.2 \mathrm{~g} \mathrm{CLA} / \mathrm{d}$ & $\begin{array}{l}\text { No significant change in weight. BFM not } \\
\text { determined. Significant decrease in SAD } \\
\text { (measure of abdominal obesity) }\end{array}$ \\
\hline Risérus et al. (2002) $)^{(60)}$ & CLA mixture or $t 10, c 12-C L A$ & $57 \mathrm{M}$ & $\begin{array}{l}\mathrm{RCT}, 12 \text { weeks, } 3.4 \mathrm{~g} \text { CLA } \\
\text { or } t 10, c 12-\mathrm{CLA} / \mathrm{d}\end{array}$ & $\begin{array}{l}\text { No significant difference in body composition } \\
\text { between the groups. Significant decrease } \\
\text { in weight, SAD and BFM within } t 10, c \\
\text { 12-CLA group. Significant decrease in SAD } \\
\text { and BFM within CLA group }\end{array}$ \\
\hline Risérus et al. (2004) & $c 9, t 11-\mathrm{CLA}$ & $25 \mathrm{M}$ & $\mathrm{RCT}, 12$ weeks, $3 \mathrm{~g} c 9, t 11-\mathrm{CLA} / \mathrm{d}$ & $\begin{array}{l}\text { No significant change in body weight between } \\
c 9, t 11-C L A \text { and placebo. Significant increase } \\
\text { in body weight within } c 9, t 11-C L A \text { group }\end{array}$ \\
\hline Gaullier et al. (2004) $)^{(65)}$ & CLA mixture & $31 \mathrm{M}, 149 \mathrm{~F}$ & $\begin{array}{l}\mathrm{RCT}, 1 \text { year, } 3.6 \mathrm{~g} \text { CLA-NEFA/d } \\
\text { or } 3.4 \mathrm{~g} \text { CLA-TAG/d }\end{array}$ & $\begin{array}{l}\text { Significant reduction in body weight (1\%) and } \\
\text { BFM (5\%). No effect on LBM }\end{array}$ \\
\hline Malpuech-Brugère et al. (2004) ${ }^{(77)}$ & $c 9, t 11-$ or $t 10, c 12-C L A$ & $82 M+F$ & $\begin{array}{l}\text { RCT, } 18 \text { weeks, } 1.5 \text { or } 3 g \text { c } 9, t 11 \text {-CLA } \\
\text { or } 1.5 \text { or } 3 \mathrm{~g} t 10, c 12 \text {-CLA per } d\end{array}$ & No significant changes in body composition \\
\hline Desroches et al. $(2005)^{(80)}$ & $\begin{array}{l}\text { Supplemented cows' } \\
\text { diets to produce } \\
\text { butter naturally enriched } \\
\text { with } c 9, t 11-\mathrm{CLA}\end{array}$ & $16 \mathrm{M}$ & $\begin{array}{l}\text { RCT, cross-over, } 4 \text { weeks, } 0.24 \text { or } \\
2.5 \mathrm{~g} \mathrm{c} 9, t 11-\mathrm{CLA} / \mathrm{d}\end{array}$ & $\begin{array}{l}\text { No significant change in body weight. BFM } \\
\text { not determined }\end{array}$ \\
\hline Gaullier et al. $(2005)^{(66)}$ & CLA mixture & $24 \mathrm{M}, 110 \mathrm{~F}$ & $\begin{array}{l}\text { Continuation of } 2004 \text { study }^{(65)}, 2 \text { years, } \\
3.4 \mathrm{~g} \mathrm{CLA-TAG/d}\end{array}$ & $\begin{array}{l}\text { Significant decrease in body weight }(2 \%) \\
\text { and BFM }(6 \%) \text {, no safety issues with long-term } \\
\text { supplementation }\end{array}$ \\
\hline Naumann et al. $(2006)^{(102)}$ & $\begin{array}{l}c 9, t 11-\text { or } t 10, c 12-C L A \\
\text { in a dairy drink }\end{array}$ & $48 \mathrm{M}, 39 \mathrm{~F}$ & $\begin{array}{l}\mathrm{RCT}, 13 \text { weeks, } 3 \mathrm{~g} c 9, t 11-\mathrm{CLA} \\
\text { or } t 10, c 12-\mathrm{CLA} \text { per d }\end{array}$ & $\begin{array}{l}\text { No significant change in body weight. } \\
\text { BFM not determined }\end{array}$ \\
\hline Gaullier et al. $(2007)^{(67)}$ & CLA mixture (Clarinol) & $93 \mathrm{M}+\mathrm{F}$ & RCT, 6 months, $3.4 \mathrm{~g} \mathrm{CLA} / \mathrm{d}$ & $\begin{array}{l}\text { BFM was significantly decreased at } 3 \text { months } \\
(1 \%) \text { and } 6 \text { months }(3.4 \%) \text {. Most BFM reduction } \\
\text { was in legs, LBM increased }\end{array}$ \\
\hline Laso et al. $(2007)^{(68)}$ & $\begin{array}{l}\text { CLA mixture (Tonalin) added } \\
\text { to skimmed milk }\end{array}$ & $33 \mathrm{M}, 11 \mathrm{~F}$ & $\mathrm{RCT}, 12$ weeks, $3 \mathrm{~g} \mathrm{CLA} / \mathrm{d}$ & $\begin{array}{l}\text { Significant decrease in BFM ( } 3 \%) \text { in overweight } \\
\text { subjects, but not in obese subjects }\end{array}$ \\
\hline Watras et al. $(2007)^{(69)}$ & CLA mixture & $8 \mathrm{M}, 32 \mathrm{~F}$ & $\mathrm{RCT}, 6$ months, $3.2 \mathrm{~g} \mathrm{CLA} / \mathrm{d}$ & $\begin{array}{l}\text { Significant decrease in BFM (4\%) and } \\
\text { body weight (1\%) }\end{array}$ \\
\hline Steck et al. $(2007)^{(57)}$ & CLA mixture & $13 \mathrm{M}, 35 \mathrm{~F}$ & $\mathrm{RCT}, 12$ weeks, 3.2 or $6.4 \mathrm{~g} \mathrm{CLA} / \mathrm{d}$ & $\begin{array}{l}\text { No significant change in body weight or BFM. } \\
\text { Significant increase in LBM within } 6.4 \mathrm{~g} / \mathrm{d} \text { group }\end{array}$ \\
\hline Syvertsen et al. $(2007)^{(58)}$ & CLA mixture (Clarinol) & $18 \mathrm{M}, 65 \mathrm{~F}$ & $\mathrm{RCT}, 6$ months, $3.4 \mathrm{~g} \mathrm{CLA} / \mathrm{d}$ & $\begin{array}{l}\text { No significant change in body weight or BFM. } \\
\text { Significant decrease in waist circumference } \\
\text { in CLA group }\end{array}$ \\
\hline Norris et al. $(2009)^{(70)}$ & CLA mixture & $35 \mathrm{~F}$ & $\mathrm{RCT}$, cross-over, 16 weeks, $6.4 \mathrm{~g} \mathrm{CLA} / \mathrm{d}$ & $\begin{array}{l}\text { Significant reduction in BMI and BFM, } \\
\text { no effect on LBM }\end{array}$ \\
\hline Herrmann et al. $(2009)^{(61)}$ & $\begin{array}{l}c 9, t 11-C L A \text { or } t 10, c 12-C L A \\
\text { or CLA mixture }\end{array}$ & $34 \mathrm{M}$ & $\mathrm{RCT}$, crossover, 4 weeks, $3.4 \mathrm{~g} \mathrm{CLA} / \mathrm{d}$ & $\begin{array}{l}\text { No significant change in body weight, BMI, waist } \\
\text { circumference or waist:hip ratio }\end{array}$ \\
\hline Zhao et al. $(2009)^{(71)}$ & CLA mixture & $\begin{array}{l}44 \mathrm{M}, 36 \mathrm{~F} \text { (subjects } \\
\text { taking blood } \\
\text { pressure medication) }\end{array}$ & $\mathrm{RCT}, 8$ weeks, $4.5 \mathrm{~g} \mathrm{CLA} / \mathrm{d}$ & $\begin{array}{l}\text { Significantly lower \%BFM and hip circumference. } \\
\text { No significant change in body weight, BMI, } \\
\text { waist circumference or waist:hip ratio }\end{array}$ \\
\hline Racine et al. (2010) $)^{(73)}$ & CLA mixture in chocolate milk & 53 children $6-10$ years & $\mathrm{RCT}, 7$ months, $3 \mathrm{~g} \mathrm{CLA} / \mathrm{d}$ & $\begin{array}{l}\text { CLA group had significantly less abdominal } \\
\text { body fat (\%) }\end{array}$ \\
\hline Sluijs et al. $(2010)^{(62)}$ & $\begin{array}{l}c 9, t 11-C L A \text { manufactured from } \\
\text { safflower-seed oil }\end{array}$ & $167 \mathrm{M}, 179 \mathrm{~F}$ & $\mathrm{RCT}, 6$ months, $4 \mathrm{~g} \mathrm{CLA} / \mathrm{d}$ & $\begin{array}{l}\text { No significant change in body weight, BMI, } \\
\text { waist circumference or waist:hip ratio }\end{array}$ \\
\hline
\end{tabular}


which was of 104 weeks' duration, and supplemented with 3.4 g 50:50 CLA/d. One study in children found that body fat gain was attenuated during prepubertal growth in 6-10-year-olds supplemented with $3.0 \mathrm{~g}$ 50:50 CLA/ $\mathrm{d}^{(73)}$. However, in a few cases it has been noted that the largest reduction in BFM occurs in the lower body (for example, legs) ${ }^{(56,67)}$. Furthermore, some studies have reported increases in lean body mass (LBM) with CLA supplementation $^{(57,64,67)}$. In the study by Blankson et al. ${ }^{(64)}$ increased LBM was only observed in the group which significantly increased their level of intensive physical training during the intervention, hence it is possible that the observed effects were, at least partially, due to increased physical activity and not CLA supplementation.

Interestingly, in another study, overweight subjects receiving 3.2 $\mathrm{g}$ of 50:50 CLA per d over a 6-month period, including the Christmas period, demonstrated a lower rate of weight gain and a $4 \%$ reduction in BFM compared with control $^{(69)}$. A study of subjects with type 2 diabetes supplemented with $6 \mathrm{~g}$ of 50:50 CLA per d for 8 weeks found that plasma concentration of $t 10, c 12$-CLA, but not $c 9, t 11$ CLA, was inversely associated with body weight, suggesting that $t 10, c 12$-CLA is the active CLA isomer in relation to weight change ${ }^{(74)}$. This is in agreement with evidence from animal studies which also points to the $t 10, c 12$-CLA isomer as being the CLA isomer which elicits BFM reductions. A meta-analysis concluded that CLA, at a dose of $3.2 \mathrm{~g} / \mathrm{d}$, produces a modest body fat loss in humans of about $0.09 \mathrm{~kg} /$ week, with the relationship being linear up to 6 months ${ }^{(75)}$. This may be partly explained by the isomerand tissue-specific effects of CLA, whereby $c 9, t 11$-CLA was found to be increased in skeletal muscle and $t 10, c 12$-CLA was incorporated into adipose tissue TAG in a subset of healthy non-obese participants ${ }^{(76)}$.

In addition to studies examining effects of CLA mixes, a number of studies have investigated the effects of individual CLA isomers on body composition. Findings from these studies show that consumption of $0.59-3 \mathrm{~g}$ $c 9, t 11$-CLA per d or $0.6-3.4 \mathrm{~g} t 10, c 12$-CLA per d does not change body composition ${ }^{(60,77-79)}$.

Currently, only three studies have been carried out which have fed subjects naturally CLA-enriched dairy products and investigated the effects on body composition ${ }^{(45,50,80)}$. In the study by Desroches et al. ${ }^{(80)}$, sixteen normolipidaemic overweight and obese men consumed butter naturally enriched with CLA ( $c 9, t 11$-CLA; $2.59 \mathrm{~g} / \mathrm{d})$, or non-enriched control butter $(0.24 \mathrm{~g} / \mathrm{d})$, for 4 weeks each in a cross-over design, and results showed no changes in body composition. Tricon et al. ${ }^{(45)}$ fed thirty-two healthy normolipidaemic men either naturally CLA-enriched or control dairy products (UHT full-fat milk, butter and cheese ( $1.42 v .0 .15 \mathrm{~g} c 9, t 11-\mathrm{CLA} / \mathrm{d})$ in a 6-week cross-over study. Similarly, no changes in body weight were observed; however, body composition was not the primary outcome of this study, but rather blood lipid profile. No changes in body composition were 
observed when subjects consumed beef and dairy products naturally enriched with $1.17 \mathrm{~g}$ CLA/d for $56 \mathrm{~d}^{(50)}$. Also, with all of these studies it is important to note that the durations (4-8 weeks) were relatively short for investigating effects on body composition.

There are many possible explanations for the lack of reproducibility in studies of CLA's effect on body composition between animals and humans. These include age, sex, genetic predisposition to fat accumulation and differences in experimental design ${ }^{(81)}$. It is interesting to note that although animal studies have evaluated the effects of CLA on weight gain over time in growing animals, the majority of human studies tend to investigate whether CLA affects weight or fat loss only in adults.

\section{Conjugated linoleic acid, lipid metabolism and atherosclerosis}

CVD are the leading cause of mortality globally ${ }^{(82)}$ and so modification of key risk factors such as LDL-cholesterol or blood TAG are key targets (for example, in the $\mathrm{UK}^{(83)}$ ). The impact of dietary fat and specific fatty acids on blood lipids has been a focus of research at least since Keys et al.'s early epidemiological work ${ }^{(84)}$, so it is not surprising that the effect of CLA on blood lipids has been investigated.

Evidence from animal studies in rabbits, hamsters and mice has suggested that CLA has the potential to modulate plasma lipid metabolism and make an impact on the development and regression of cholesterol-induced atherosclerotic plaques ${ }^{(85)}$.

In rabbits, mixed-isomer CLA, fed at levels of $0.1-1 \%$ of diet over periods of 13 to 22 weeks, has been shown to reduce cholesterol deposition in the $\operatorname{aorta}^{(86)}$ and result in significant regression of established atherosclerotic lesions ${ }^{(87)}$. Furthermore, mixed-isomer CLA at a lower dose $(0.05 \%)$ has been shown to be sufficient to decrease lesion development in rabbits ${ }^{(88)}$. Supplementation with either $c 9, t 11-C L A$ or $t 10, c 12-C L A$ results in similar reductions in lesion development to that seen with mixed-CLA isomer supplementation ${ }^{(89)}$.

Studies in hamsters that have supplemented with CLA over periods of 6-12 weeks, using different CLA isomers and doses, have shown mixed results, but there is evidence of improvements in lipid profile ${ }^{(90,91)}$. In addition, there is some indication that CLA in conjunction with a lower-fat diet may reduce atherosclerotic lesions in the hamster ${ }^{(85)}$. It has been suggested that $t 10, c 12$-CLA may be the protective isomer in relation to lipid profile, as in the study by Gavino et al. ${ }^{(91)}$, a CLA mix, but not the $c 9, t 11$-CLA isomer, improved the lipid profile of hamsters.

In mice, studies with supplemental CLA carried out over periods of 4-20 weeks, using different CLA isomers and doses, have also shown mixed results ${ }^{(85)}$. There has been one promising report of CLA (80:20 blend of $c 9, t 11$-CLA and $t 10, c 12$-CLA) resulting in marked regression of atherosclerotic lesions in apoE mice ${ }^{(92)}$. In addition, there is some evidence of opposing effects of CLA isomers, with one study in mice showing $c 9, t 11$-CLA decreasing and $t 10, c 12-C L A$ increasing atherosclerotic lesion area ${ }^{(93)}$.

Further to the above studies which have supplemented animals' diets with commercial CLA preparations, studies have been carried out to investigate the anti-atherogenic effects of inclusion of dairy foods, and other foods such as eggs, naturally enriched with CLA, into the diets of animals ${ }^{(94-98)}$. The results of these studies have shown that CLA can improve plasma lipid profile and decrease atherosclerosis-related biomarkers. Overall, at present there is no general consensus as to the effect of CLA supplementation on lipids or atherosclerosis in animals. Furthermore, most animal studies that have suggested protective anti-atherogenic effects have generally provided CLA doses greater than those achievable in the human diet.

Despite much investigation, the precise mechanisms by which CLA affects lipid metabolism and adipose tissue are not fully elucidated. However, it is thought that CLA modulates energy expenditure, apoptosis, fatty acid oxidation, lipolysis and lipogenesis ${ }^{(99)}$. As discussed in the previous section, the $t 10, c 12$-CLA isomer is thought to exert effects on body composition, partly due to a reduction in lipid uptake by adipocytes due to effects of CLA on stearoylCoA desaturase and lipoprotein lipase activity ${ }^{(4)}$.

In humans epidemiological studies on dietary CLA intakes and prevalence of atherosclerosis have not been carried out to date. However, over the past decade, numerous human intervention studies have investigated the effect of CLA on lipids and other markers of atherosclerotic risk (Table 4), the results of which have been highly inconsistent, possibly due to the use of different isomers and varying doses. The majority of these studies have used commercial mixed- or pureisomer CLA preparations, at levels of 1.7 to $6.8 \mathrm{~g} / \mathrm{d}$, over periods of 4 to 13 weeks, and have not shown any overall effect on plasma lipid or lipoprotein concentrations, compared with placebo, in normal-weight and overweight subjects $^{(44,46,50,52,61-64,73,78,100-105)}$. However, one study did report significant within-group reductions in total cholesterol and LDL-cholesterol with doses of 1.7 and $3.4 \mathrm{~g} \mathrm{CLA} / \mathrm{d}^{(64)}$, but it was stated that the reductions were not clinically important.

Some studies have reported that supplementation with commercial CLA preparations can have a negative effect on the lipid profile. For example, a significant decrease in HDL-cholesterol was observed on supplementing with $3.4 \mathrm{~g} t 10, c 12$-CLA per $\mathrm{d}$ in obese men with the metabolic syndrome ${ }^{(60)}$, and in healthy subjects who were supplementing their diets with $0.7-1.4 \mathrm{~g}$ CLA mix per $\mathrm{d}^{(51)}$. There is some evidence to suggest that CLA (mixtures and individual isomers) can induce lipid peroxidation $^{(78,103)}$; however, it is not known whether this effect of CLA could be pro-atherogenic in humans.

In contrast, other studies have shown a positive effect of CLA, with $3 \mathrm{~g}$ 50:50 CLA mix per d lowering fasting 
WS Nutrition Research Reviews

Table 4. Effect of conjugated linoleic acid (CLA) on blood lipid concentrations in human subjects

\begin{tabular}{|c|c|c|c|c|}
\hline Reference & Form of CLA & Number of subjects & Design & Overall result \\
\hline $\begin{array}{l}\text { Blankson et al. } \\
(2000)^{(64)}\end{array}$ & CLA mixture & $47 M+F$ & RCT, 12 weeks, $1.7,3.4,5.1$ or $6.8 \mathrm{~g} \mathrm{CLA} / \mathrm{d}$ & $\begin{array}{l}\text { No significant effect on HDL, LDL or tChol } \\
\text { between groups }\end{array}$ \\
\hline $\begin{array}{l}\text { Mougios et al. } \\
(2001)^{(51)}\end{array}$ & CLA mixture & $13 \mathrm{M}, 9 \mathrm{~F}$ & $\begin{array}{l}8 \text { weeks, } 0.7 \mathrm{~g} \mathrm{CLA} / \mathrm{d} \text { for weeks } 1-4 \text {, } \\
1.4 \mathrm{~g} \mathrm{CLA} / \mathrm{d} \text { for weeks } 5-8\end{array}$ & Significant decrease in HDL \\
\hline $\begin{array}{l}\text { Risérus et al. } \\
\qquad(2001)^{(101)}\end{array}$ & CLA mixture & $24 \mathrm{M}$ & $\mathrm{RCT}, 4$ weeks, $4.2 \mathrm{~g} \mathrm{CLA} / \mathrm{d}$ & No significant effect on cholesterol or TAG \\
\hline $\begin{array}{l}\text { Benito et al. } \\
\quad(2001)^{(100)}\end{array}$ & CLA mixture & $17 \mathrm{~F}$ & RCT, 13 weeks, $3.9 \mathrm{~g} \mathrm{CLA} / \mathrm{d}$ & No significant effect on HDL, LDL, tChol or TAG \\
\hline $\begin{array}{l}\text { Smedman \& } \\
\text { Vessby } \\
(2001)^{(52)}\end{array}$ & CLA mixture & $50 M+F$ & $\mathrm{RCT}, 12$ weeks, $4.2 \mathrm{~g} \mathrm{CLA} / \mathrm{d}$ & $\begin{array}{l}\text { No significant effect on apoA-1, apoB, HDL, } \\
\text { LDL, NEFA, tChol, TAG or VLDL }\end{array}$ \\
\hline $\begin{array}{l}\text { Noone et al. } \\
(2002)^{(106)}\end{array}$ & $\begin{array}{l}\text { CLA mixture or } 80: 20 c 9, t 11 \\
\text { and } t 10, c 12-C L A\end{array}$ & $18 \mathrm{M}, 33 \mathrm{~F}$ & 8 weeks, $3 \mathrm{~g}$ 50:50 CLA or $3 \mathrm{~g} 80: 20$ CLA per d & $\begin{array}{l}\text { 50:50 CLA decreased TAG, 80:20 CLA } \\
\text { decreased VLDL }\end{array}$ \\
\hline $\begin{array}{l}\text { Risérus et al. } \\
\qquad(2002)^{(60)}\end{array}$ & CLA mixture or $t 10, c 12-C L A$ & $57 \mathrm{M}$ & $\mathrm{RCT}, 12$ weeks, $3.4 \mathrm{~g}$ CLA or $t 10, c 12-\mathrm{CLA}$ per d & $\begin{array}{l}\text { Significant decrease in HDL with both CLA } \\
\text { mix and } t 10, c 12-C L A\end{array}$ \\
\hline $\begin{array}{l}\text { Petridou et al. } \\
\qquad(2003)^{(44)}\end{array}$ & CLA mixture & $16 \mathrm{~F}$ & RCT, 6 weeks, $2.1 \mathrm{~g} \mathrm{CLA} / \mathrm{d}$ & No significant effect on tChol, TAG or HDL \\
\hline $\begin{array}{l}\text { Moloney et al. } \\
\qquad(2004)^{(107)}\end{array}$ & CLA mixture & $32 M+F$ & $\mathrm{RCT}, 8$ weeks, $3 \mathrm{~g} \mathrm{CLA} / \mathrm{d}$ & $\begin{array}{l}\text { Significant increase in HDL, and decrease in } \\
\text { LDL:HDL }\end{array}$ \\
\hline $\begin{array}{l}\text { Tricon et al. } \\
\qquad(2004)^{(134)}\end{array}$ & $c 9, t 11-$ or $t 10, c 12-C L A$ & $39-49 \mathrm{M}$ & $\begin{array}{l}\mathrm{RCT}, \text { cross-over, } 8 \text { weeks, } 0.59,1.19 \text { or } 2.38 \mathrm{~g} \\
c 9, t 11-\mathrm{CLA} / \mathrm{d} \text { or } 0.6,1.3 \text { or } 2.5 \mathrm{~g} t 10, c 12-\mathrm{CLA} / \mathrm{d}\end{array}$ & $\begin{array}{l}\text { t10,c12-CLA increases LDL:HDL and total } \\
\text { cholesterol:HDL, but } c 9, t 11-C L A \\
\text { decreases these }\end{array}$ \\
\hline $\begin{array}{l}\text { Risérus et al. } \\
\qquad(2004)^{(78)}\end{array}$ & $c 9, t 11-\mathrm{CLA}$ & $25 \mathrm{M}$ & RCT, 12 weeks, $3 \mathrm{~g} c 9, t 11-\mathrm{CLA} / \mathrm{d}$ & $\begin{array}{l}\text { No significant effect on HDL, LDL, tChol, TAG } \\
\text { or VLDL. Significant increase in lipid } \\
\text { peroxidation (8-iso-PGF } F_{2 \alpha} \text { and } \\
\text { 15-keto-dihydro-PGF } \text { PG }_{2 \alpha} \text { ) }\end{array}$ \\
\hline $\begin{array}{l}\text { Naumann et al. } \\
(2006)^{(102)}\end{array}$ & $\begin{array}{l}c 9, t 11-\text { or } t 10, c 12-C L A \\
\text { in a dairy drink }\end{array}$ & $48 \mathrm{M}, 39 \mathrm{~F}$ & RCT, 13 weeks, $3 \mathrm{~g} c 9, t 11$-CLA or $t 10, c 12-$ CLA per $d$ & No significant effect on TAG, HDL or LDL \\
\hline $\begin{array}{l}\text { Lambert et al. } \\
\qquad(2007)^{(46)}\end{array}$ & CLA mixture & $62 M+F$ & RCT, 12 weeks, $3.9 \mathrm{~g} \mathrm{CLA} / \mathrm{d}$ & $\begin{array}{l}\text { No CLA specific effects. tChol and LDL } \\
\text { significantly decreased in both groups } \\
\text { and HDL decreased in women }\end{array}$ \\
\hline $\begin{array}{l}\text { Raff et al. } \\
\qquad(2008)^{(103)}\end{array}$ & $\begin{array}{l}\text { Foods baked with butter } \\
\text { synthetically enriched with } \\
\text { CLA mixture }\end{array}$ & $38 \mathrm{M}$ & RCT, 5 weeks, $4.6 \mathrm{~g} \mathrm{CLA} / \mathrm{d}$ & $\begin{array}{l}\text { No significant effect on HDL, LDL, tChol } \\
\text { or TAG. Significant increase in lipid } \\
\text { peroxidation (8-iso-PGF } \text { PG }_{2 \alpha} \text { ) }\end{array}$ \\
\hline $\begin{array}{l}\text { Turpeinen et al. } \\
\qquad(2008)^{(104)}\end{array}$ & $c 9, t 11-\mathrm{CLA}$ & $12 \mathrm{M}, 28 \mathrm{~F}$ & $\mathrm{RCT}, 12$ weeks, $2 \mathrm{~g} \mathrm{CLA} / \mathrm{d}$ & No significant changes in plasma lipids \\
\hline $\begin{array}{l}\text { Herrmann et al. } \\
\qquad(2009)^{(61)}\end{array}$ & $\begin{array}{l}c 9, t 11-C L A \text { or } t 10, c 12-C L A \\
\text { or CLA mixture }\end{array}$ & $34 \mathrm{M}$ & $\mathrm{RCT}$, crossover, 4 weeks, $3.4 \mathrm{~g} \mathrm{CLA} / \mathrm{d}$ & $\begin{array}{l}\text { No significant changes in tChol, HDL, LDL, } \\
\text { TAG or blood pressure }\end{array}$ \\
\hline $\begin{array}{l}\text { Zhao et al. } \\
\qquad(2009)^{(71)}\end{array}$ & CLA mixture & $\begin{array}{l}44 \mathrm{M}, 36 \mathrm{~F} \text { (subjects taking } \\
\text { blood pressure medication) }\end{array}$ & RCT, 8 weeks, $4.5 \mathrm{~g} \mathrm{CLA} / \mathrm{d}$ & $\begin{array}{l}\text { Significant effects on HDL, LDL:HDL, blood } \\
\text { pressure. No significant effect on tChol, LDL, } \\
\text { TAG or VLDL }\end{array}$ \\
\hline $\begin{array}{l}\text { Racine et al. } \\
(2010)^{(73)}\end{array}$ & CLA mixture in chocolate milk & 53 children aged $6-10$ years & RCT, 7 months, $3 \mathrm{~g}$ CLA/d & $\begin{array}{l}\text { No significant changes in LDL. CLA group had } \\
\text { significant decreases in HDL }\end{array}$ \\
\hline $\begin{array}{l}\text { Sluijs et al. } \\
(2010)^{(62)}\end{array}$ & $\begin{array}{l}c 9, t 11-C L A \text { manufactured from } \\
\text { safflower-seed oil }\end{array}$ & $167 \mathrm{M}, 179 \mathrm{~F}$ & RCT, 6 months, $4 \mathrm{~g}$ CLA/d or placebo & $\begin{array}{l}\text { No significant effect on HDL, LDL, TAG, tChol } \\
\text { or blood pressure }\end{array}$ \\
\hline $\begin{array}{l}\text { Wanders et al. } \\
\quad(2010)^{(49) \star}\end{array}$ & $\begin{array}{l}\text { Foods enriched with CLA-rich oil, } \\
7 \% \text { of total energy as CLA } \\
\text { (78\% c9,t11-CLA and } \\
17 \%+10, c 12-C L A)\end{array}$ & $25 \mathrm{M}, 36 \mathrm{~F}$ & $\begin{array}{l}\text { RCT, crossover, } 21 \mathrm{~d} \text {, oleic (control) or industrial } \\
\text { trans-fatty acids or } 26.8 \mathrm{~g} \text { CLA isomers/d }\end{array}$ & $\begin{array}{l}\text { Significantly higher tChol, HDL, LDL, apoB } \\
\text { relative to control diet. No significant difference } \\
\text { in TAG }\end{array}$ \\
\hline
\end{tabular}


TAG, and 3g 80:20 CLA mix per d decreasing VLDL, in healthy subjects ${ }^{(106)}$. Furthermore, $3 \mathrm{~g}$ 50:50 CLA per d was shown to significantly increase HDL-cholesterol and significantly decrease LDL:HDL-cholesterol in patients with type 2 diabetes ${ }^{(107)}$. Consumption of foods enriched with $26.8 \mathrm{~g}$ CLA $/ \mathrm{d}$ led to a significant positive effect on HDL concentration and a significant lowering of LDL-cholesterol ${ }^{(49)}$. Interestingly, Tricon et al. ${ }^{(79)}$ observed divergent responses in plasma lipids with CLA supplementation, with $t 10, c 12$-CLA $(0.6-2.5 \mathrm{~g} / \mathrm{d})$ increasing LDL:HDLcholesterol and total:HDL-cholesterol and c9,t11-CLA $(0.59-2.38 \mathrm{~g} / \mathrm{d})$ decreasing these ratios, with no dosedependent effect observed. Elevated cholesterol ratios of LDL:HDL and total:HDL-cholesterol are independent risk factors for $\mathrm{CHD}^{(108,109)}$.

Recently, the effects of consuming dairy products, naturally rich in CLA or naturally enriched with CLA, on lipids in human subjects have been examined in four studies $^{(45,50,80,110)}$. Three of these studies manipulated cows' diets to produce dairy products naturally enriched with CLA ${ }^{(44,50,80)}$. In the study by Desroches et al. ${ }^{(80)}$, normolipidaemic overweight and obese men consumed butter naturally enriched with CLA ( $c 9, t 11$-CLA; $2.59 \mathrm{~g} / \mathrm{d})$, or non-enriched control butter $(0.24 \mathrm{~g} / \mathrm{d})$, for 4 weeks. Results showed plasma lipid subfraction levels (VLDL, LDL and HDL) were not significantly different between the two treatments; however, consumption of the nonenriched butter resulted in a significantly greater reduction of total cholesterol, total:HDL-cholesterol and LDL: HDL-cholesterol compared with the CLA-enriched butter, a result which was contradictory to the hypothesis. Tricon et al. ${ }^{(45)}$ fed healthy normolipidaemic men either naturally CLA-enriched or control dairy products (UHT full-fat milk, butter and cheese (1.42 v. $0.15 \mathrm{~g} c 9, t 11$-CLA per d)) in a 6-week cross-over study. Overall, lipid subfractions were not affected; however, a small but significant increase in LDL:HDL-cholesterol was observed. These results were similar to findings by Brown et al. ${ }^{(50)}$ where consumption of beef and dairy products rich in CLA (1.17 g CLA/d) for $56 \mathrm{~d}$ did not alter blood lipid profile.

A small, cross-over study in ten healthy subjects found that consumption of cheese made from naturally CLA-rich sheep's milk ( $0.25 \mathrm{~g}$ c9,t11-CLA per d) for 10 weeks had no effect on plasma lipids, as compared with consumption of a regular cows' cheese ${ }^{(110)}$. The daily intake of CLA was confirmed as being $0.25 \mathrm{~g} c 9, t 11$-CLA in correspondence with the author. It is important to note that using cows' milk cheese as a control was not ideal, due to the fact that it has a very different fatty acid profile compared with sheep's cheese. Overall these studies have shown no significant effect of treatment with dairy products naturally rich in CLA or naturally enriched with CLA on plasma lipids.

Dairy products which are naturally enriched in CLA are also higher in trans-vaccenic acid (trans-18: 1), lower in SFA content, and slightly higher in $n-3$ PUFA content 
than conventional dairy products, due to the feeding strategies employed for enrichment ${ }^{(15)}$. It has been suggested that consuming trans-fatty acids impairs the lipid profile by lowering HDL-cholesterol and raising LDL-cholesterol levels ${ }^{(111)}$. Whether the content of trans-vaccenic acid in naturally CLA-enriched dairy products could counteract the potential benefit of CLA on the lipid profile unclear. The current evidence examining the intake of trans-fatty acids from animal sources and associations with CHD presents a confusing picture, particularly given the higher than typically consumed levels of trans-fatty acids used within studies ${ }^{(112-116)}$. However, it is unclear whether the partial conversion of trans-vaccenic to c9,t11-CLA in human intestines, liver and adipose tissue promotes adverse or beneficial effects on lipid profile ${ }^{(113,117)}$.

The reason for the inconsistent and mostly neutral results in relation to the effects of CLA on lipids in human studies compared with animal studies is unclear. However, it is important to note that while animal studies examined the effect of using CLA to supplement hyperlipidaemic animals that were eating atherogenic diets, human studies examined the effect of supplementing diets of normolipidaemic subjects with CLA. Furthermore, it is conceivable that the anti-atherosclerotic effects of CLA observed in animal studies may be due to mechanisms other than effects on lipids, for instance anti-inflammatory effects, as atherosclerosis is an inflammatory disease.

\section{Conjugated linoleic acid, inflammation and immune} effects

Inflammation underlies a wide range of conditions. For example, as noted above, obesity is now recognised as a state of chronic or low-grade systemic inflammation, due to the abnormal circulating levels of inflammatory molecules, including TNF $\alpha$, leptin and IL-6, which are secreted by adipose tissue ${ }^{(41)}$. In addition, inflammation is central to atherosclerosis ${ }^{(118)}$ and the metabolic syndrome ${ }^{(119)}$.

In vitro studies have shown that CLA has anti-inflammatory effects. CLA (CLA mix, or $c 9, t 11$-CLA or $t 10, c 12$-CLA) is associated with a lower mRNA expression of the inflammatory mediators cyclo-oxygenase- $2, \mathrm{TNF} \alpha$, and inducible NO synthase, and decreases production of induced $\mathrm{PGE}_{2}$, NO, IL-6 and IL-1 $\beta$ in mouse macrophage cells ${ }^{(120)}$. The $c 9, t 11$-CLA isomer inhibits induced eosinophil activation, decreases transcription of TNF $\alpha$, IL- 6 and IL-12 in Caco-2 cells and enhances IL-10 production in murine dendritic cells $^{(121-123)}$. Furthermore, both $c 9, t 11$-CLA and $t 10, c 12-$ CLA reduce $\mathrm{PGE}_{2}$ and thromboxane $\mathrm{B}_{2}$ concentrations in human macrophages ${ }^{(124)}$

Animal studies have been carried out to determine if CLA exerts anti-inflammatory effects in vivo; however, results to date have been inconsistent. Three animal studies have found a CLA mix to be anti-inflammatory ${ }^{(125-127)}$. Obese rats fed 1.5\% CLA mix for 8 weeks were found to have less adipose TNF $\alpha$ mRNA expression; however, other markers of inflammation did not change ${ }^{(127)}$. Butz et $a{ }^{(126)}$ reported that mice fed $0.5 \%$ CLA mix for 3 weeks had less plasma TNF $\alpha$ compared with mice on a control diet. In pigs fed 2\% CLA mix for $14 \mathrm{~d}$, a decrease in induced elevation and mRNA expression of pro-inflammatory cytokines (IL- 6 and TNF- $\alpha$ ), and an increase in an anti-inflammatory cytokine (IL-10) were observed. Furthermore, a molecular aspect of the same study determined $t 10, c 12$-CLA to be the main isomer to which the anti-inflammatory effect can be attributed ${ }^{(125)}$. However, in contrast to these findings, two studies have established $t 10, c 12$-CLA to have pro-inflammatory effects, where mice fed $0.5 \% t 10, c 12$-CLA for $14 \mathrm{~d}$ showed induced pro-inflammatory cytokine transcripts in white adipose tissue $^{(128)}$, and short-term supplementation with $t 10, c 12$ CLA in mice also increased pro-inflammatory cytokine gene expression in a study ${ }^{(129)}$.

Human intervention studies have investigated the effect of CLA (both commercial preparations and naturally CLA-enriched dairy products) on various biomarkers of inflammation (Table 5). Results to date have been mixed, with most studies either showing an increase in inflammatory markers, or no change. Three studies that have supplemented subjects with a CLA mixture at doses of 4.2 to $6.4 \mathrm{~g} / \mathrm{d}$, over periods of 12 to 16 weeks, have found increases in plasma levels of C-reactive protein $(C R P)^{(57,130,131)}$. There were no significant effects on inflammatory markers including CRP and a range of interleukins when subjects were supplemented with 4 to $4.5 \mathrm{~g}$ CLA mixture/ $\mathrm{d}^{(132,133)}$. Two studies with CLA added to foods showed no effect on plasma CRP levels; however, the duration of these trials was relatively short $(5$ and 8 weeks $)^{(63,103)}$. Furthermore, two crossover studies that provided $c 9, t 11$-CLA at doses of $4 \mathrm{~g} / \mathrm{d}^{(62)}$ or $0.6-2.4 \mathrm{~g} / \mathrm{d}$ and $0.6-2.5 \mathrm{~g} / \mathrm{d} t 10, c 12-$ CLA $^{(134)}$, for 6 months and 8 weeks respectively, observed no change in plasma CRP concentrations.

Supplementation with $t 10, c 12$-CLA at doses of $3-3.4 \mathrm{~g} / \mathrm{d}$ for 12-13 weeks has produced inconsistent results. A study in obese men with the metabolic syndrome found increased plasma CRP levels; on the other hand, a study in overweight men and women demonstrated no effect on plasma CRP, or on other markers of inflammation $^{(135,136)}$. In the case of $c 9, t 11$-CLA, supplementation with similar doses (3g) for similar durations (12-13 weeks) has also resulted in contrasting results, with one study reporting increased excretion of a pro-inflammatory marker (15-keto-dihydro-PGF2 $\alpha$ ) in obese subjects ${ }^{(78)}$, and another study reporting no effect on a range of pro-inflammatory markers in overweight subjects ${ }^{(135)}$.

As described in the previous section, the effect of feeding subjects dairy products which are naturally enriched in $c 9, t 11$-CLA (due to the manipulation of diets of cows) has been investigated in two studies to date ${ }^{(45,80)}$. In these studies, daily doses of $1.4-2.6 \mathrm{~g} c 9, t 11$-CLA were fed for durations of $4-6$ weeks, and no changes in plasma CRP 
Table 5. Effect of conjugated linoleic acid (CLA) on inflammation and other immune indices in human subjects

\begin{tabular}{|c|c|c|c|c|}
\hline Reference & Form of CLA & Number of subjects & Design & Overall result \\
\hline $\begin{array}{l}\text { Kelley et al. } \\
\quad(2000)^{(137)}\end{array}$ & CLA mixture & $17 \mathrm{~F}$ & 9 weeks, $3.9 \mathrm{~g} \mathrm{CLA} / \mathrm{d}$ & $\begin{array}{l}\text { No significant effects on any immune indices (number of } \\
\text { circulating white blood cells, granulocytes, mono- } \\
\text { cytes, lymphocytes, and their subsets, lymphocytes } \\
\text { proliferation in response to phytohemagglutinin, and } \\
\text { influenza vaccine, serum influenza antibody titers, } \\
\text { and DTH response) }\end{array}$ \\
\hline $\begin{array}{l}\text { Risérus et al. } \\
\qquad(2002)^{(60)}\end{array}$ & CLA mixture or $t 10, c 12-C L A$ & $57 \mathrm{M}$ & $\begin{array}{l}\text { RCT, } 12 \text { weeks, } 3.4 \mathrm{~g} \text { CLA or } t 10, c 12- \\
\text { CLA per d }\end{array}$ & $t 10, c 12-C L A$ significantly increased CRP \\
\hline
\end{tabular}

$(2002)^{(60)}$

Risérus et al.

$(2004)^{(78)}$

Tricon et al.

c9, t11-CLA

$25 \mathrm{M}$

$c 9, t 11$ - or $t 10, c 12-C L A$

$39-49 \mathrm{M}$

Smedman etal. CLA mixture

$(2005)(130)$

Desroches

et al.

$(2005)^{(80)}$

Ramakers et al.

$(2005)^{(135)}$

Song et al.

(2005)

Nugent et al.
$(2005)^{(138)}$

ricon et al.

$(2006)^{(4)}$

Mullen et al.
$(2007)^{(140)}$

Steck et al.

$(2007)^{(57)}$

Tholstrup et at. $(2008)^{(131)}$

Raff et al. $(2008)^{(103)}$

Turpeinen et al.
$(2008)^{(104)}$

Sofi et al.

$(2009)^{(110)}$

Zhao et al.

$(2009)^{(71)}$

Sluijs et al. $(2010)^{(62)}$

Supplemented cows' diets to produce butter naturally enriched with $c 9, t 11-\mathrm{CLA}$

\section{$c 9, t 11-C L A$ or $t 10, c 12-C L A$}

CLA mixture

\section{$c 9, t 11$ - or $t 10, c 12-C L A$ blends}

Supplemented cows' diets to produce milk naturally enriched with $c 9, t 11-C L A$ to make products

CLA mixture

CLA mixture

CLA mixture or $c 9, t 11-C L A$, added to oil

Foods baked with butter synthetically enriched with CLA mixture$$
\text { c9,t11-CLA }
$$

Sheep's cheese naturally rich in $c 9, t 11-\mathrm{CLA}$

CLA mixture

$c 9, t 11-C L A$ manufactured from safflower-seed oil
CLA per d

$50 \mathrm{M}+\mathrm{F} \quad \mathrm{RCT}, 12$ weeks, $4.2 \mathrm{~g} \mathrm{CLA} / \mathrm{d}$
$16 \mathrm{M}$

$38 \mathrm{M}+\mathrm{F}$

$8 \mathrm{M}, 20 \mathrm{~F}$

$20 \mathrm{M}, 35 \mathrm{~F}$

$32 \mathrm{M}$

$30 \mathrm{M}$

$13 \mathrm{M}, 35 \mathrm{~F}$

$75 \mathrm{~F}$

$38 \mathrm{M}$

RCT, cross-over, 4 weeks, 0.24 or $2.5 \mathrm{~g}$ $c 9, t 11-\mathrm{CLA} / \mathrm{d}$

RCT, 13 weeks, $3 \mathrm{~g} c 9, t 11-\mathrm{CLA}$ or

t10,c12-CLA per d

RCT, 12 weeks, $3 \mathrm{~g} \mathrm{CLA} / \mathrm{d}$

RCT, 8 weeks, $2 \mathrm{~g} 50: 50 \mathrm{CLA} / \mathrm{d}$ or $1.8 \mathrm{~g}$ $80: 20 \mathrm{CLA} / \mathrm{d}$

$\mathrm{RCT}$, cross-over, 6 weeks, 0.15 or $1.42 \mathrm{~g}$ $c 9, t 11-\mathrm{CLA} / \mathrm{d}$

$\mathrm{RCT}, 8$ weeks, $2.2 \mathrm{~g} \mathrm{CLA} / \mathrm{d}$

$\mathrm{RCT}, 12$ weeks, 3.2 or $6.4 \mathrm{~g} \mathrm{CLA} / \mathrm{d}$

RCT, 16 weeks, $5.5 \mathrm{~g}$ CLA mix/d or $5.5 \mathrm{~g}$ $c 9, t 11-C L A / d$

RCT, 5 weeks, $4.6 \mathrm{~g} \mathrm{CLA} / \mathrm{d}$

RCT, 12 weeks, $2 \mathrm{~g} \mathrm{CLA} / \mathrm{d}$

Cross-over, 10 weeks, $0.25 \mathrm{~g} c 9, t 11$ CLA/d

$44 \mathrm{M}, 36 \mathrm{~F}$ (subjects

taking blood pressure

medication

$167 \mathrm{M}, 179 \mathrm{~F}$

$\mathrm{RCT}, 6$ months, $4 \mathrm{~g} \mathrm{CLA} / \mathrm{d}$ or placebo
RCT, 12 weeks, $3 \mathrm{~g} c 9, t 11-\mathrm{CLA} / \mathrm{d}$

$\mathrm{RCT}$, cross-over, 8 weeks, $0.59,1.19$ or $2.38 \mathrm{~g} c 9, t 11-\mathrm{CLA} / \mathrm{d}$ or $0.6,1.3$ or $2.5 \mathrm{~g}$ $t 10, c 12-C L A / d$

C9,t11-CLA significantly increased a pro-inflammatory marker (15-keto-dihydro-PGF $F_{2 \alpha}$ )

Both isomers decreased mitogen-induced T lymphocyte activation. No significant effect on lymphocytes or CRP

Significant increase in CRP. No significant change in

TNF $\alpha$, TNF receptors or VCAM-1

No significant effect on CRP

No significant change in CRP, IL-6, IL-8 and TNFo

Significant decrease in pro-inflammatory cytokines TNF $\alpha$ and IL-1 $\beta$. Significant increase in anti-inflammatory cytokine IL-10

Ex vivo: no significant effect on PBMC IL-4 production In vivo: no significant effect on ICAM-1, $\mathrm{PGE}_{2}, \mathrm{LTB}_{4}$

No significant effect on IL-6, VCAM-1, CRP, E-selectin

No significant change in CRP, IL-6 fibrinogen

6.4 g CLA significantly increased CRP and IL-6

CLA mix, compared with $c 9, t 11-C L A$, significantly increased CRP and fibrinogen. PAl-1, VCAM-1, ICAM-1,MCP-1, IL-6 and TNF $\alpha$ were unaffected No significant effect on inflammatory markers (CRP, PAl-1, FVII-C)

Significant effects on 8-iso-PGF ${ }_{2 \alpha}$, 15-keto-dihydro$\mathrm{PGF}_{2 \alpha}$, EDN, GM-CSF, IFN- $\gamma$, TNF $\alpha$ and sneezing Significant decrease in cytokines; IL-6, IL-8 and TNF $\alpha$. Significant decrease in platelet aggregation

Significant effects on adiponectin, leptin. No significant effect on ACE activity

No significant effect on CRP 
concentrations and other inflammatory markers were observed. In contrast, a study by Sofi et al. ${ }^{(110)}$ found that consumption of sheep cheese, naturally rich in CLA ( $0.25 \mathrm{~g} c 9$, t11-CLA per d), for 10 weeks decreased circulating levels of the pro-inflammatory cytokines IL-6, IL-8 and TNF $\alpha$, compared with consumption of a control cows' cheese. However, as noted above, this study was small, poorly controlled and may not have been adequately powered for the multiple variables measured.

Some studies have investigated other immune effects in addition to inflammation. A study where the diets of young women were supplemented with a CLA mixture at $3.9 \mathrm{~g} / \mathrm{d}$ for 9 weeks found that no indices of immune status were affected (such as the number of circulating leucocytes; granulocytes; monocytes; lymphocytes and their subsets; lymphocytes proliferation in response to phytohaemagglutinin and influenza vaccine; and serum influenza antibody titres) ${ }^{(137)}$. However, the sample size was small, at seventeen. In a larger study, with fifty-five subjects, Nugent et al. ${ }^{(138)}$ found that either a 50:50 CLA mixture or an 80:20 CLA mixture at about $2 \mathrm{~g} / \mathrm{d}$ had minimal effects on lymphocytes and cytokines, and had no additional benefit on immune function compared with linoleic acid. CLA supplementation has also been linked to reduced symptoms of birch pollen allergy ${ }^{(104)}$ and improved airway hyper-responsiveness in asthmatics ${ }^{(132)}$. However, a second study in asthmatics found no attenuation of airway inflammation or bronchoconstrictive response ${ }^{(133)}$.

However, Song et al. $^{(139)}$ found that supplementing twenty-eight males and females with 3 g CLA 50:50 for 12 weeks had beneficial effects on immune function as it decreased pro-inflammatory cytokines (TNF $\alpha$ and IL-1 $\beta$ ) and increased an anti-inflammatory cytokine (IL-10). Furthermore, Tricon et al. ${ }^{(134)}$ found that supplementing men with 0.6 to about $2.5 \mathrm{~g}$ of either $c 9, t 11$-CLA or $t 10, c 12$-CLA per d decreased mitogen-induced T lymphocyte activation dose-dependently (however, lymphocytes and cytokines were unaffected). Mullen $e t a l .{ }^{(140)}$ showed that $2.2 \mathrm{~g}$ CLA 50:50 per $\mathrm{d}$ for 8 weeks decreased stimulated peripheral blood mononuclear cell IL-2 secretion, but did not affect other markers including plasma levels of IL-6, CRP, fibrinogen or TNF $\alpha$, in thirty men.

Overall, studies investigating the effect of CLA (both supplements and naturally CLA-enriched products) on immune indices and inflammation provide inconsistent results.

\section{Conjugated linoleic acid, insulin resistance and diabetes}

In addition to the potential anti-atherogenic, anti-obesity and anti-inflammatory properties of CLA, the effects on diabetes have also been examined. As previously stated, increases in overweight and obesity have been concurrent with increases in type 2 diabetes, which is characterised by insulin resistance and occurs as a result of excess adipose 


\section{NS Nutrition Research Reviews}

Table 6. Effect of conjugated linoleic acid (CLA) on insulin resistance in human subjects

\begin{tabular}{|c|c|c|c|c|}
\hline Reference & Form of CLA & Number of subjects & Design & Overall result \\
\hline Noone et al. (2002) $)^{(106)}$ & $\begin{array}{l}\text { CLA mixture or } 80: 20 \\
c 9, t 11 \text { and } t 10, c 12-C L A\end{array}$ & $18 \mathrm{M}, 33 \mathrm{~F}$ & $\begin{array}{l}\text { RCT with OGTT, } 8 \text { weeks, } \\
3 \mathrm{~g} 50: 50 \text { CLA or } 80: 20 \text { CLA per d }\end{array}$ & No effect on insulin or glucose \\
\hline Risérus et al. $(2002)^{(60)}$ & CLA mixture or $t 10, c 12-C L A$ & $57 \mathrm{M}$ & $\begin{array}{l}\text { RCT, } 12 \text { weeks, } 3.4 \mathrm{~g} \text { CLA or } \\
t 10, c 12-C L A \text { per } d\end{array}$ & $\begin{array}{l}t 10, c 12-C L A \text { increased insulin } \\
\text { resistance and glycaemia }\end{array}$ \\
\hline Risérus et al. (2004) ${ }^{(78)}$ & $c 9, t 11-\mathrm{CLA}$ & $25 \mathrm{M}$ & RCT, 12 weeks, $3 \mathrm{~g} c 9, t 11-\mathrm{CLA} / \mathrm{d}$ & $\begin{array}{l}c 9, t 11-C L A \text { increased insulin compared } \\
\text { with placebo in obese men }\end{array}$ \\
\hline Eyjolfson et al. (2004) $)^{(155)}$ & CLA mixture & $4 \mathrm{M}, 12 \mathrm{~F}$ & $\begin{array}{l}\mathrm{RCT}, 8 \text { weeks, } 4 \mathrm{~g} \mathrm{CLA} / \mathrm{d}, \mathrm{OGTT} \\
\text { at } 0,4 \text { and } 8 \text { weeks }\end{array}$ & $\begin{array}{l}\text { Improvements for insulin resistance, } \\
\text { corresponding decrease in fasting insulin, } \\
\text { though large variations in response }\end{array}$ \\
\hline Gaullier et al. (2004) $)^{(65)}$ & CLA mixture & $31 \mathrm{M}, 149 \mathrm{~F}$ & $\begin{array}{l}\text { RCT with OGTT, } 1 \text { year, } 3.6 \mathrm{~g} \text { CLA-NEFA } / \mathrm{d} \\
\text { or } 3.4 \mathrm{~g} \text { CLA-TAG/d }\end{array}$ & No effects on glucose or insulin \\
\hline Moloney et al. (2004) ${ }^{(107)}$ & CLA mixture & $32 M+F$ & RCT with EGC, 8 weeks, $3 \mathrm{~g} \mathrm{CLA} / \mathrm{d}$ & $\begin{array}{l}\text { Negative effect on glucose and insulin in } \\
\text { type } 2 \text { diabetics }\end{array}$ \\
\hline Gaullier et al. (2005) $)^{(66)}$ & CLA mixture & $24 \mathrm{M}, 110 \mathrm{~F}$ & $\begin{array}{l}\text { Continuation of } 2004 \text { study }{ }^{(65)} \text {, with OGTT, } \\
2 \text { years, } 3.4 \mathrm{~g} \text { CLA-TAG/d }\end{array}$ & $\begin{array}{l}\text { No effects on glucose or HbA1c. Original } \\
\text { CLA-TAG group significant increase } \\
\text { in insulin between } 12 \text { and } 24 \text { months, } \\
\text { though authors contend that } \\
\text { not diabetogenic }\end{array}$ \\
\hline Naumann et al. $(2006)^{(102)}$ & $\begin{array}{l}c 9, t 11-\text { or } t 10, c 12-C L A \text { in a } \\
\text { dairy drink }\end{array}$ & $48 \mathrm{M}, 39 \mathrm{~F}$ & $\begin{array}{l}\mathrm{RCT}, 13 \text { weeks, } 3 \mathrm{~g} c 9, t 11-\mathrm{CLA} \\
\text { or } t 10, c 12-\mathrm{CLA} \text { per } \mathrm{d}\end{array}$ & No change in glucose or insulin \\
\hline Tricon et al. $(2006)^{(45)}$ & $\begin{array}{l}\text { Supplemented cows' diets to } \\
\text { produce milk naturally enriched } \\
\text { with } c 9, t 11-C L A \text { to make products }\end{array}$ & $32 \mathrm{M}$ & $\begin{array}{l}\text { RCT, cross-over, } 6 \text { weeks, } 0.15 \\
\text { or } 1.42 \mathrm{~g} \mathrm{c} 9, t 11-\mathrm{CLA} / \mathrm{d}\end{array}$ & No effects on insulin or glucose \\
\hline Gaullier et al. (2007)(67) & CLA mixture (Clarinol) & $93 \mathrm{M}+\mathrm{F}$ & RCT with OGTT, 6 months, $3.4 \mathrm{~g}$ CLA/d & No effects on insulin or glucose \\
\hline Laso et al. $(2007)^{(68)}$ & $\begin{array}{l}\text { CLA mixture (Tonalin) added to } \\
\text { skimmed milk }\end{array}$ & $33 \mathrm{M}, 11 \mathrm{~F}$ & $\mathrm{RCT}, 12$ weeks, $3 \mathrm{~g} \mathrm{CLA} / \mathrm{d}$ & No change in insulin resistance \\
\hline Syvertsen et al. $(2007)^{(58)}$ & CLA mixture (Clarinol) & $\begin{array}{l}18 \mathrm{M}, 65 \mathrm{~F} \text { (of these, } \\
41 \text { completed } \\
\text { substudy using } \\
\text { euglycaemic } \\
\text { insulin clamp) }\end{array}$ & RCT, 6 months, $3.4 \mathrm{~g}$ CLA/d & $\begin{array}{l}\text { No effects on insulin resistance in } \\
\text { main study or subsample }\end{array}$ \\
\hline Tarnopolsky et al. $(2007)^{(154)}$ & CLA mixture & $19 \mathrm{M}, 20 \mathrm{~F}$ & $\begin{array}{l}\text { RCT with OGTT, with and without } \\
\text { resistance training, } \\
6 \text { months, } 6 \mathrm{~g} \mathrm{CLA} / \mathrm{d} \text { plus } 5 \mathrm{~g} \text { creatine } / \mathrm{d} \\
\text { or placebo plus creatine }\end{array}$ & No effects on glucose or insulin \\
\hline Raff et al. $(2008)^{(103)}$ & $\begin{array}{l}\text { Foods baked with butter synthetically } \\
\text { enriched with CLA mixture }\end{array}$ & $38 \mathrm{M}$ & RCT, 5 weeks, $4.6 \mathrm{~g} \mathrm{CLA} / \mathrm{d}$ & No effect on insulin or glucose \\
\hline Raff et al. (2009) ${ }^{(56)}$ & CLA mixture or $c 9, t 11-C L A$ & $75 \mathrm{~F}$ & 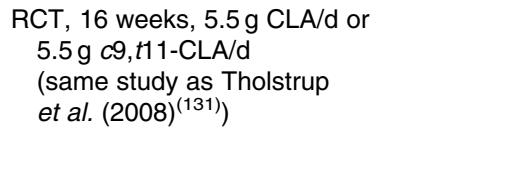 & $\begin{array}{l}\text { No effect on glucose or insulin, HOMA-IR. } \\
\text { However, women with the highest waist } \\
\text { circumference (3rd tertile, } 94-109 \mathrm{~cm}) \\
\text { had higher fasting insulin in the CLA-mix } \\
\text { group than in control and } \\
\text { c9,t11 groups - post hoc analysis }\end{array}$ \\
\hline Turpeinen et al. $(2008)^{(104)}$ & $c 9, t 11-\mathrm{CLA}$ & $12 \mathrm{M}, 28 \mathrm{~F}$ & $\mathrm{RCT}, 12$ weeks, $2 \mathrm{~g} \mathrm{CLA} / \mathrm{d}$ & $\begin{array}{l}\text { No significant effect on glucose, insulin, } \\
\text { HOMA-IR or QUICKI }\end{array}$ \\
\hline Ahren et al. (2009) $)^{(153)}$ & CLA mixture (Clarinol) & $\begin{array}{l}\text { Younger } 12 \text { lean, } \\
10 \text { obese; older } \\
16 \text { lean, } 11 \text { obese M }\end{array}$ & $\begin{array}{l}\text { RCT with EGC, cross-over, } \\
12 \text { weeks, } 3 \mathrm{~g} \text { CLA/d plus } \\
3 \mathrm{~g} n-3 \text { long-chain PUFA/d }\end{array}$ & $\begin{array}{l}\text { No effects in young lean or obese or } \\
\text { older lean adults. Obese older adults } \\
\text { estimated insulin resistance was } \\
\text { increased with supplementation }\end{array}$ \\
\hline Norris et al. $(2009)^{(70)}$ & CLA mixture & $35 \mathrm{~F}$ & RCT, cross-over, 16 weeks, $6.4 \mathrm{~g}$ CLA/d & No effect on glucose or insulin \\
\hline Herrmann et al. $(2009)^{(61)}$ & $\begin{array}{l}c 9, t 11-C L A \text { or } t 10, c 12-C L A \text { or } \\
\text { CLA mixture }\end{array}$ & $34 \mathrm{M}$ & $\mathrm{RCT}$, crossover, 4 weeks, $3.4 \mathrm{~g} \mathrm{CLA} / \mathrm{d}$ & $\begin{array}{l}\text { No significant changes in glucose } \\
\text { or HOMA-IR }\end{array}$ \\
\hline
\end{tabular}




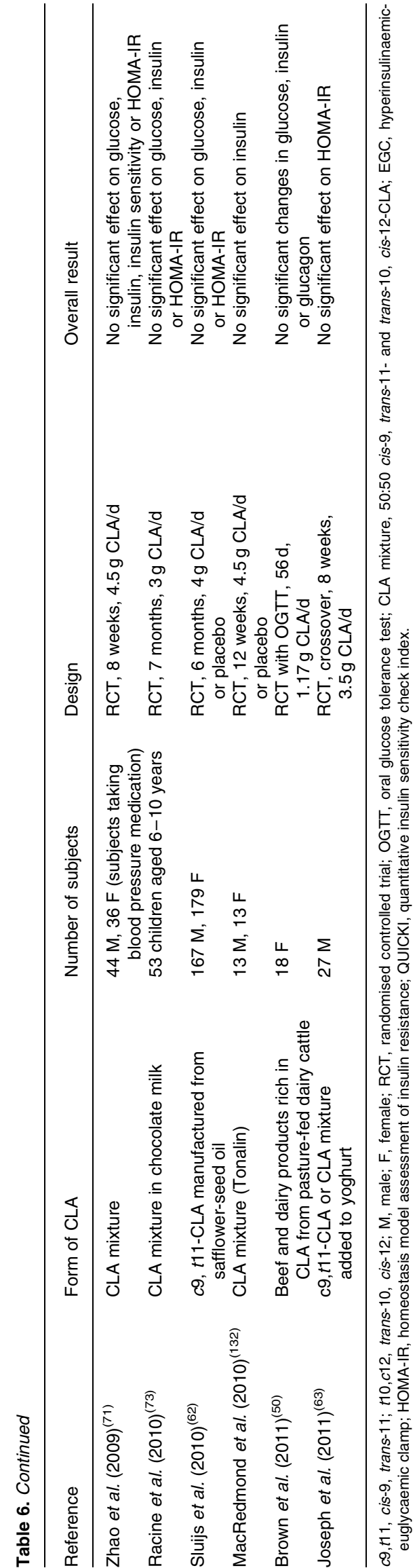

tissue. A 5\% reduction in body weight has been shown to decrease insulin resistance in overweight and obese subjects ${ }^{(43,141,142)}$. Therefore the observed modest reductions in body weight with CLA mixtures at $3 \mathrm{~g} / \mathrm{d}$ may also improve insulin resistance.

Overall, the results from both animal and in vitro work are conflicting, with the effects of CLA on insulin resistance examined in addition to other outcomes (atherogenic and obesogenic properties). The vast majority of studies have examined the effects of CLA isomer mixtures, though some results do suggest isomeric differences ${ }^{(143)}$. In a mouse model, feeding a diet rich in $t 10, c 12$-CLA induced insulin resistance whereas $c 9, t 11$-CLA improved lipid metabolism without impairing insulin action ${ }^{(144)}$ by possible mediation of the pro-inflammatory state ${ }^{(145)}$. Similarly, studies with male Zucker diabetic fatty (ZDF) rats feeding a 50:50 blend of CLA reduced glucose and insulin concentrations $^{(146)}$, although the diet with 91\% c9,t11-CLA showed no effect ${ }^{(147)}$. In contrast, in another mouse model of diabetes, a blend of CLA isomers induced marked lipodystrophic insulin resistance and glucose tolerance ${ }^{(148,149)}$. In the same strain of young and ageing mice, supplementation with the individual isomers or a CLA mix demonstrated divergent responses ${ }^{(148,149)}$. Supplementation, with $c 9, t 11$-CLA elicited no effects on indices of insulin resistance, plasma insulin and glucose, whereas supplementation with $t 10, c 12$-CLA or a CLA mix increased plasma glucose, insulin and homeostasis model assessment of insulin resistance (HOMA-IR). However, during an intravenous glucose tolerance test, mice supplemented with c9,t11-CLA eliminated glucose faster than the control, $t 10, c 12-C L A-$ or CLA mix-fed mice ${ }^{(150)}$. These data highlight the importance of not just measuring plasma glucose and insulin, as true effects may only be apparent when more robust measures of insulin resistance are used.

One group has used a proteomics approach for eliciting the interactions between CLA isomers and diseases in an animal model ${ }^{(151)}$. Proteomic techniques measure changes in the protein complement of a biological system and enable modelling of biological processes in response to dietary interventions ${ }^{(150)}$. In a study with apoE mice consuming $7 \% c 9, t 11$-CLA or $t 10, c 12$-CLA or control (linoleic acid), results suggested that $c 9, t 11$-CLA exerted antidiabetic effects due to altered expression of markers, whereas $t 10, c 12$-CLA asserted pro-diabetic effects ${ }^{(60,78,152)}$. Overall, this study suggests that $c 9, t 11$-CLA potentially contributes to a less severe inflammatory response or protection against the development of atherosclerosis. However, conducting a trial in human subjects would be prohibitively expensive and require a rigorously controlled protocol in order to examine the effects of CLA supplementation on protein structure and function.

Currently the anti-diabetic properties of CLA in human subjects (Table 6) cannot be fully determined, as few studies are undertaken using rigorous measures of insulin resistance such as the hyperinsulinaemic-euglycaemic 
clamp $^{(107,153)}$ or the oral glucose tolerance test $^{(50,56,58,65-67,106,154,155)}$. Indeed the majority of results on the anti-diabetic properties of CLA relate to studies where only fasting plasma or serum glucose or insulin have been measured, are not the main focus of the study and typically have small sample sizes. Given these limitations, it is perhaps not surprising that the overall results show no effects of CLA supplementation $^{(56,61,62,65-67,70,71,104,106,132,154)}$ or consumption of CLA-enriched products ${ }^{(45,63,73,102,103)}$ on glucose and insulin. However, supplementing with a CLA mixture has shown beneficial effects on insulin resistance in healthy male subjects ${ }^{(155)}$ and type 2 diabetic subjects ${ }^{(74)}$. In contrast, a negative effect on insulin resistance was reported in type 2 diabetic patients; however, this may have been due to the bias in the glucose tolerance between the supplementation and placebo groups and may not have been due to CLA supplementation ${ }^{(144)}$.

A recent study also found increased insulin resistance in older obese subjects, but no effects of combined CLA $-n-3$ supplementation in lean or obese younger subjects or older lean subjects ${ }^{(153)}$. Supplementation with the individual isomers, $c 9, t 11$-CLA or $t 10, c 12$-CLA increased insulin resistance $(+15 \%)$ in obese men with the metabolic syndrome $^{(60,78)}$, whereas a CLA isomer mixture did not affect insulin resistance ${ }^{(60)}$. Furthermore, lipid peroxidation increased relative to placebo when the individual isomers were administered, but the differences did not remain significant when adjusted for changes in lipid peroxidation $^{(60,78)}$. The authors of these papers suggest that irrespective of the CLA isomer, CLA-induced lipid peroxidation may mediate insulin resistance. However, further work is required, particularly studies where the hyperinsulinaemic-euglycaemic clamp is utilised ${ }^{(152,156)}$. The conflicting responses to increased CLA intake in both human and animal studies do not currently imply compelling anti-diabetic properties of CLA. Thus, studies should be designed that provide rigorous measures of insulin resistance in subjects of varying age groups and weight status ${ }^{(157)}$.

\section{Conjugated linoleic acid and bone health}

Bone is a complex tissue system whereby the skeleton is continually renewed through the resorption (breakdown) of existing bone and the formation of new bone (remodelling). Peak bone mass in humans usually occurs late in the second or early in the third decade of life with a progressive decline in bone mineral density starting in the fourth decade of life for both men and women ${ }^{(158)}$. Bone modelling (children and young adults) or remodelling (adults) is influenced by many factors including nutritional status, hormones and mechanical loading. One of the consequences of low bone turnover or remodelling is the development of osteoporosis, particularly in white, postmenopausal women. In the UK, the costs of osteoporosis to the National Health Service are estimated at

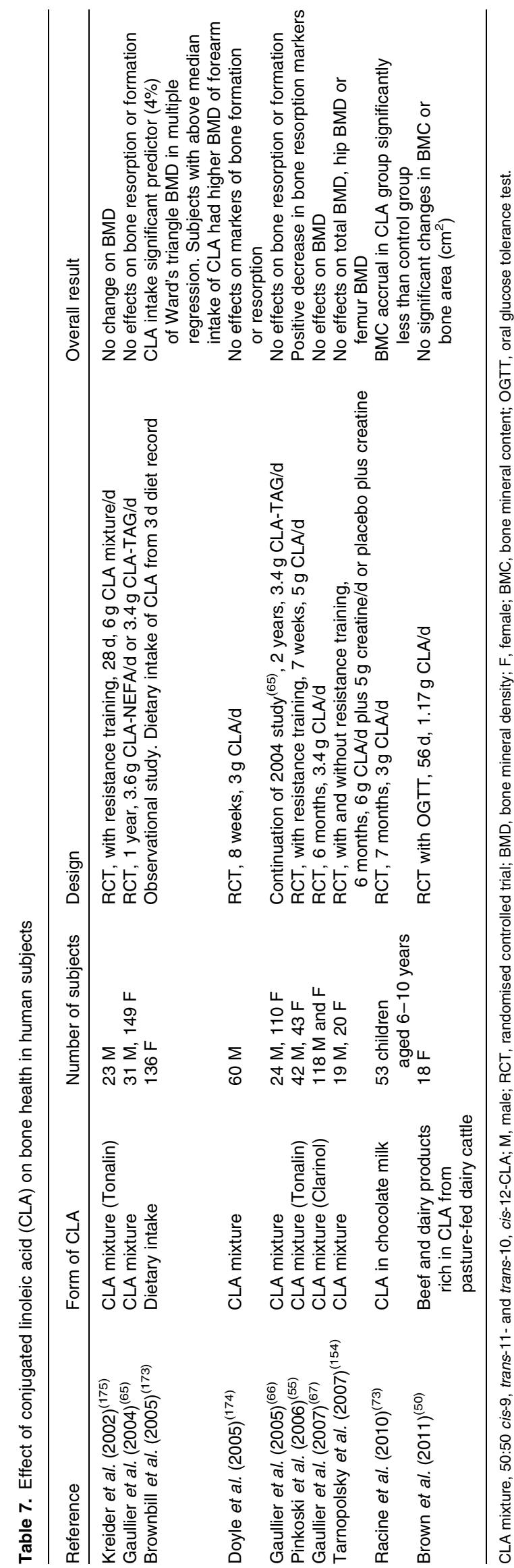


$£ 2.3$ billion per year or $£ 6$ million per $\mathrm{d}$, with almost 3 million individuals diagnosed with osteoporosis ${ }^{(159)}$. Thus, strategies that attenuate decreases in bone mass are of great importance, with much of research focused on $\mathrm{Ca}$, vitamin $\mathrm{D}$, protein and vitamin $\mathrm{K}$ intakes ${ }^{(160)}$. However, other nutrients, including CLA, have been the focus of research due to influences on bone mass and metabolism $^{(18,161-163)}$.

The majority of work on CLA and bone metabolism has been conducted using human cells and animal models, particularly those reflecting postmenopausal women. Supplementation studies have demonstrated decreased $\mathrm{PGE}_{2}$ production in rats, but results were dependent on the CLA concentration levels ${ }^{(164-168)} \cdot \mathrm{PGE}_{2}$ is an important factor in the regulation of bone metabolism, including bone formation as well as bone resorption ${ }^{(158)}$. $\mathrm{PGE}_{2}$ production increases in postmenopausal bone loss due to oestrogen deficiency ${ }^{(158)}$. CLA may also stimulate Ca absorption, thus making more $\mathrm{Ca}$ available for bone formation ${ }^{(164,169)}$. Recently, Park et al. ${ }^{(170)}$ reanalysed previous studies in mice and showed that extra Ca (0.66\%) in the diet improved CLA effects on bone mass in male, but not female mice. A recent review concluded that based on the current evidence from in vitro and animal studies the addition of CLA, overall, improves bone strength and density ${ }^{(161)}$. However, the majority of studies currently published were conducted using CLA isomer mixtures. Only two studies have examined the differences between the $c 9, t 11$ and $t 10, c 12$ isomers and found no direct effects on bone, but rather attenuation of parathyroid hormone concentration ${ }^{(171,172)}$.

Whilst there are numerous publications examining the effects of CLA and bone formation in cell and animal models, studies in human subjects are lacking (Table 7). Data from an observational study showed that in postmenopausal women dietary intake of CLA was a weak but significant predictor of Ward's triangle bone mineral density $^{(173)}$. The same study also found that subjects with above median intake of CLA had higher bone mineral density of the forearm. In contrast, supplementation with a CLA mix (3.0-3.4 g/d) did not affect bone formation or resorption in healthy lean, overweight, obese men and women ${ }^{(65-67,174)}$. A further two studies in young and elderly subjects who completed resistance training in addition to CLA supplementation $(6 \mathrm{~g} / \mathrm{d})$ also demonstrated no change in bone mineral density and bone mass ${ }^{(154,175)}$. Brown et al. $^{(50)}$ reported no change in bone mineral content when subjects consumed a CLA-enriched diet, although the study duration was only $56 \mathrm{~d}$, an insufficient length of time for observing changes in bone mineral content. In children, significantly less bone mineral content accretion occurred in the CLA supplemented after 7 months ${ }^{(73)}$; however, the reasons are not fully elucidated. Currently, the only human study to demonstrate a positive association between CLA supplementation ( $5 \mathrm{~g} / \mathrm{d}$ ) and bone found a decrease in bone resorption markers and increase in $\mathrm{LBM}^{(55)}$. However, this study did not identify whether the increases in LBM were due to increased muscle or bone mass and whether it was an artifact of the 7-week resistance training programme. Since there are relatively few human studies (four out of seven studies where bone was not the primary outcome examined), the lack of consistency in protocols, measurement of bone metabolites and small sample sizes hinder a clear conclusion between the effects of CLA and bone.

\section{Overall conclusions}

The overall evidence from the studies examined here demonstrates a lack of definitive and reproducible results, particularly in relation to the consumption of naturally enriched CLA products, as the number of published studies is low relative to the number on synthetic supplements. The majority of randomised controlled trials are conducted with CLA supplements, with varying mixtures of isomers and dosage levels. However, the evidence from animal studies is promising, but extrapolation from animal to human studies is difficult due to the differences in the amount of CLA used. For example, in animal studies the observed benefits of CLA on bone are between $0.1-1 \%$ CLA of total weight of diet ${ }^{(173)}$. For men consuming on average $3.0 \mathrm{~kg}$ food and beverages per $\mathrm{d}$, this is equivalent to 3-30 g CLA/d; for women consuming about $2.2 \mathrm{~kg}$ food and beverages per $\mathrm{d}$, this equates to $2.2-22 \mathrm{~g} \mathrm{CLA} / \mathrm{d}^{(176)}$. In addition, given the differences in study protocols, relatively small sample sizes and other methodological issues (including measurement of dietary CLA intakes ${ }^{(8)}$ and accurate measurement of body composition), it is not surprising that there is a lack of consensus on what health claims could be applicable to CLA, either natural or synthetic products. Current submissions on CLA health claims to the European Food Safety Authority (EFSA) include seven for body weight/LBM, two on immune function, two on antioxidant properties and one relating to insulin. The present review suggests that the only possible candidate would be in relation to the synthetic t10,c12-CLA isomer and reductions in body fat.

\section{Acknowledgements}

The present review was prepared as part of a project funded by Scottish Enterprise (Glasgow, UK). Nino Binns Consulting provides consultancy in nutrition and food regulation to a variety of commercial clients.

T. A. M. and E. M. K. drafted the review. J. M. W. W., N. B. and M. B. E. L. commented on the review.

There are no conflicts of interest.

\section{References}

1. European Parliament and Council of the European Union (2006) Regulation (EC) No 1924/2006 of the European 
Parliament and of the Council of 20 December 2006 on nutrition and health claims made on foods. In Official Journal of the European Union, pp. L404/9-L404/25, issue no. 1924.

2. Chin S, Liu W, Storkson JM, et al. (1992) Dietary sources of conjugated dienoic isomer of linoleic acid, a newly recognized class of anticarcinogens. J Food Compost Anal 5, 185-197.

3. Banni S (2002) Conjugated linoleic acid metabolism. Curr Opin Lipidol 13, 261-266.

4. Pariza MW, Park Y \& Cook ME (2001) The biologically active isomers of conjugated linoleic acid. Prog Lipid Res 40, 283-298.

5. Lock AL \& Bauman DE (2004) Modifying milk fat composition of dairy cows to enhance fatty acids beneficial to human health. Lipids 39, 1197-1206.

6. Christie WW (1999) Analysis of conjugated linoleic acid: an overview. In Advances in Conjugated Linoleic Acid Research, vol. 2, pp. 1-12 [JL Sebedio, WW Christie and RO Adlof, editors]. Champaign, IL: AOCS Press.

7. Ha YL, Grimm NK \& Pariza MW (1987) Anticarcinogens from fried ground beef: heat-altered derivatives of linoleic acid. Carcinogenesis 8, 1881-1887.

8. Ritzenthaler KL, McGuire MK, Falen R, et al. (2001) Estimation of conjugated linoleic acid intake by written dietary assessment methodologies underestimates actual intake evaluated by food duplicate methodology. $J$ Nutr 131, 1548-1554.

9. Mushtaq S, Heather Mangiapane E \& Hunter KA (2010) Estimation of $c i s-9$, trans-11 conjugated linoleic acid content in UK foods and assessment of dietary intake in a cohort of healthy adults. Br J Nutr 103, 1366-1374.

10. Parodi PW (2003) Conjugated linoleic acid in food. In Advances in Conjugated Linoleic Acid Research, vol. 2, pp. 101-122 [JL Sebedio, WW Christie and RO Adlof, editors]. Champaign, IL: AOCS Press.

11. Parodi PW (1999) Conjugated linoleic acid: the early years. In Advances in Conjugated Linoleic Acid Research, vol. 1, pp. 1-12 [MP Yurawecz, MM Mossoba, JK Kramer, MW Pariza and GJ Nelson, editors]. Champaign, IL: AOCS Press.

12. Dhiman TR, Anand GR, Satter LD, et al. (1999) Conjugated linoleic acid content of milk from cows fed different diets. J Dairy Sci 82, 2146-2156.

13. Ellis KA, Innocent G, Grove-White D, et al. (2006) Comparing the fatty acid composition of organic and conventional milk. J Dairy Sci 89, 1938-1950.

14. Stanton C, Murphy J, McGrath E, et al (2003) Animal feeding strategies for conjugated linoleic acid enrichment of milk. In Advances in Conjugated Linoleic Acid Research, vol. 2, pp. 123-145 [JL Sebedio, WW Christie and RO Adlof, editors]. Champaign, IL: AOCS Press.

15. Jones EL, Shingfield KJ, Kohen C, et al. (2005) Chemical, physical, and sensory properties of dairy products enriched with conjugated linoleic acid. J Dairy Sci 88, 2923-2937.

16. Burdge GC, Tricon S, Morgan R, et al. (2005) Incorporation of cis-9 trans-11 conjugated linoleic acid and vaccenic acid (trans-11 18:1) into plasma and leucocyte lipids in healthy men consuming dairy products naturally enriched in these fatty acids. Br J Nutr 94, 237-243.

17. Parodi PW (1999) Conjugated linoleic acid and other anticarcinogenic agents of bovine milk fat. J Dairy Sci $\mathbf{8 2}$, 1339-1349.

18. Bhattacharya A, Banu J, Rahman M, et al. (2006) Biological effects of conjugated linoleic acids in health and disease. J Nutr Biochem 17, 789-810.

19. Kelley NS, Hubbard NE \& Erickson KL (2007) Conjugated linoleic acid isomers and cancer. J Nutr 137, 2599-2607.
20. Belury MA (1995) Conjugated dienoic linoleate: a polyunsaturated fatty acid with unique chemoprotective properties. Nutr Rev 53, 83-89.

21. Ip C, Chin SF, Scimeca JA, et al. (1991) Mammary cancer prevention by conjugated dienoic derivative of linoleic acid. Cancer Res 51, 6118-6124.

22. Ip C, Singh M, Thompson HJ, et al. (1994) Conjugated linoleic acid suppresses mammary carcinogenesis and proliferative activity of the mammary gland in the rat. Cancer Res 54, 1212-1215.

23. Palombo JD, Ganguly A, Bistrian BR, et al. (2002) The antiproliferative effects of biologically active isomers of conjugated linoleic acid on human colorectal and prostatic cancer cells. Cancer Lett 177, 163-172.

24. Beppu F, Hosokawa M, Tanaka L, et al. (2006) Potent inhibitory effect of trans 9, trans 11 isomer of conjugated linoleic acid on the growth of human colon cancer cells. J Nutr Biochem 17, 830-836.

25. Yasui Y, Suzuki R, Kohno H, et al. (2007) 9-Trans, 11-trans conjugated linoleic acid inhibits the development of azoxymethane-induced colonic aberrant crypt foci in rats. Nutr Cancer 59, 82-91.

26. Ip C, Banni S, Angioni E, et al. (1999) Conjugated linoleic acid-enriched butter fat alters mammary gland morphogenesis and reduces cancer risk in rats. J Nutr 129, 2135-2142.

27. Lavillonniere F, Chajes V, Martin JC, et al. (2003) Dietary purified cis-9,trans-11 conjugated linoleic acid isomer has anticarcinogenic properties in chemically induced mammary tumors in rats. Nutr Cancer 45, 190-194.

28. Hubbard NE, Lim D \& Erickson KL (2003) Effect of separate conjugated linoleic acid isomers on murine mammary tumorigenesis. Cancer Lett 190, 13-19.

29. Ip MM, McGee SO, Masso-Welch PA, et al. (2007) The $t 10, c 12$ isomer of conjugated linoleic acid stimulates mammary tumorigenesis in transgenic mice over-expressing erbB2 in the mammary epithelium. Carcinogenesis $\mathbf{2 8}$, $1269-1276$.

30. Aro A, Mannisto S, Salminen I, et al. (2000) Inverse association between dietary and serum conjugated linoleic acid and risk of breast cancer in postmenopausal women. Nutr Cancer 38, 151-157.

31. Chajes V, Lavillonniere F, Ferrari P, et al. (2002) Conjugated linoleic acid content in breast adipose tissue is not associated with the relative risk of breast cancer in a population of French patients. Cancer Epidemiol Biomarkers Prev $\mathbf{1 1}$ 672-673.

32. Chajes V, Lavillonniere F, Maillard V, et al. (2003) Conjugated linoleic acid content in breast adipose tissue of breast cancer patients and the risk of metastasis. Nutr Cancer 45, 17-23.

33. Voorrips LE, Brants HA, Kardinaal AF, et al. (2002) Intake of conjugated linoleic acid, fat, and other fatty acids in relation to postmenopausal breast cancer: the Netherlands Cohort Study on Diet and Cancer. Am J Clin Nutr 76, 873-882.

34. Larsson SC, Bergkvist L \& Wolk A (2009) Conjugated linoleic acid intake and breast cancer risk in a prospective cohort of Swedish women. Am J Clin Nutr 90, 556-560.

35. Larsson SC, Bergkvist L \& Wolk A (2005) High-fat dairy food and conjugated linoleic acid intakes in relation to colorectal cancer incidence in the Swedish Mammography Cohort. Am J Clin Nutr 82, 894-900.

36. McCann SE, Ip C, Ip MM, et al. (2004) Dietary intake of conjugated linoleic acids and risk of premenopausal and postmenopausal breast cancer Western New York Exposures and Breast Cancer Study (WEB Study). Cancer Epidemiol Biomarkers Prev 13, 1480-1484. 
37. Farnworth ER, Chouinard YP, Jacques H, et al. (2007) The effect of drinking milk containing conjugated linoleic acid on fecal microbiological profile, enzymatic activity, and fecal characteristics in humans. Nutr J 9, 6-15.

38. Venkatramanan S, Chouinard YP, Jacques H, et al. (2010) Milk enriched with conjugated linoleic acid fails to alter blood lipids or body composition in moderately overweight, borderline hyperlipidemic individuals. $J$ Am Coll Nutr 29, 152-159.

39. World Cancer Research Fund \& American Institute for Cancer Research (2007) WCRF/AICR Expert Report, Food, nutrition, physical activity and the prevention of cancer: a global perspective http://www.dietandcancerreport.org/ (accessed 26 October 2009)

40. Craig R \& Mindell J (2008) Health Survey for England 2006 Latest Trends. London: The Information Centre.

41. Forsythe LK, Wallace JM \& Livingstone MBE (2008) Obesity and inflammation: the effects of weight loss. Nutr Res Rev 21, 117-133.

42. Wahle K, Heys S \& Rotondo D (2004) Conjugated linoleic acids: are they beneficial or detrimental to health? Progr Lipid Res 43, 553-587.

43. Brown JM \& McIntosh MK (2003) Conjugated linoleic acid in humans: regulation of adiposity and insulin sensitivity. J Nutr 133, 3041-3046.

44. Petridou A, Mougios V \& Sagredos A (2003) Supplementation with CLA: isomer incorporation into serum lipids and effect on body fat of women. Lipids 38, 805-811.

45. Tricon S, Burdge GC, Jones EL, et al. (2006) Effects of dairy products naturally enriched with cis-9,trans-11 conjugated linoleic acid on the blood lipid profile in healthy middleaged men. Am J Clin Nutr 83, 744-753

46. Lambert EV, Goedecke JH, Bluett K, et al. (2007) Conjugated linoleic acid versus high-oleic acid sunflower oil: effects on energy metabolism, glucose tolerance, blood lipids, appetite and body composition in regularly exercising individuals. Br J Nutr 97, 1001-1011.

47. Nazare JA, de la Perriere AB, Bonnet F, et al. (2007) Daily intake of conjugated linoleic acid-enriched yoghurts: effects on energy metabolism and adipose tissue gene expression in healthy subjects. Br J Nutr 97, 273-280.

48. American Diabetes Association (2008) Standards of medical care in diabetes. Diabetes Care 31, Suppl. 1, S12-S54.

49. Wanders AJ, Brouwer IA, Siebelink E, et al. (2010) Effect of a high intake of conjugated linoleic acid on lipoprotein levels in healthy human subjects. PLoS One 5, e9000.

50. Brown AW, Trenkle AH \& Beitz DC (2011) Diets high in conjugated linoleic acid from pasture-fed cattle did not alter markers of health in young women. Nutr Res 31, $33-41$.

51. Mougios V, Matsakas A, Petridou A, et al. (2001) Effect of supplementation with conjugated linoleic acid on human serum lipids and body fat. $J$ Nutr Biochem 12, 585-594.

52. Smedman A \& Vessby B (2001) Conjugated linoleic acid supplementation in humans - metabolic effects. Lipids 36, 773-781

53. Thom E, Wadstein J \& Gudmundsen O (2001) Conjugated linoleic acid reduces body fat in healthy exercising humans. J Int Med Res 29, 392-396.

54. Colakoglu S, Colakoglu M, Taneli F, et al. (2006) Cumulative effects of conjugated linoleic acid and exercise on endurance development, body composition, serum leptin and insulin levels. J Sports Med Phys Fitness 46, 570-577.

55. Pinkoski C, Chilibeck PD, Candow DG, et al. (2006) The effects of conjugated linoleic acid supplementation during resistance training. Med Sci Sports Exerc 38, 339-348.
56. Raff M, Tholstrup T, Toubro S, et al. (2009) Conjugated linoleic acids reduce body fat in healthy postmenopausal women. J Nutr 139, 1347-1352.

57. Steck SE, Chalecki AM, Miller P, et al. (2007) Conjugated linoleic acid supplementation for twelve weeks increases lean body mass in obese humans. J Nutr 137, 1188-1193.

58. Syvertsen C, Halse J, Hoivik HO, et al. (2007) The effect of 6 months supplementation with conjugated linoleic acid on insulin resistance in overweight and obese. Int $J$ Obes 31, 1148-1154

59. Berven G, Bye A, Hals O, et al. (2000) Safety of conjugated linoleic acid (CLA) in overweight or obese human volunteers. Eur J Lipid Sci Technol 102, 455-462.

60. Risérus U, Arner P, Brismar K, et al. (2002) Treatment with dietary trans 10 cis 12 conjugated linoleic acid causes isomerspecific insulin resistance in obese men with the metabolic syndrome. Diabetes Care 25, 1516-1521.

61. Herrmann J, Rubin D, Häsler R, et al. (2009) Isomer-specific effects of CLA on gene expression in human adipose tissue depending on PPAR 2 P12A polymorphism: a double blind, randomized, controlled cross-over study. Lipids Health Dis 18, 35.

62. Sluijs I, Plantinga Y, de Roos B, et al. (2010) Dietary supplementation with cis-9,trans-11 conjugated linoleic acid and aortic stiffness in overweight and obese adults. $A m J$ Clin Nutr 91, 175-183.

63. Joseph SV, Jacques H, Plourde M, et al. (2011) Conjugated linoleic acid supplementation for 8 weeks does not affect body composition, lipid profile, or safety biomarkers in overweight, hyperlipidemic men. J Nutr 141, 1286-1291.

64. Blankson H, Stakkestad JA, Fagertun H, et al. (2000) Conjugated linoleic acid reduces body fat mass in overweight and obese humans. J Nutr 130, 2943-2948.

65. Gaullier JM, Halse J, Hoye K, et al. (2004) Conjugated linoleic acid supplementation for $1 \mathrm{y}$ reduces body fat mass in healthy overweight humans. Am J Clin Nutr 79, 1118-1125.

66. Gaullier JM, Halse J, Hoye K, et al. (2005) Supplementation with conjugated linoleic acid for 24 months is well tolerated by and reduces body fat mass in healthy, overweight humans. J Nutr 135, 778-784.

67. Gaullier JM, Halse J, Hoivik HO, et al. (2007) Six months supplementation with conjugated linoleic acid induces regional-specific fat mass decreases in overweight and obese. Br J Nutr 97, 550-560.

68. Laso N, Brugué E, Vidal J, et al. (2007) Effects of milk supplementation with conjugated linoleic acid (isomers cis-9trans-11 and trans-10, cis-12) on body composition and metabolic syndrome components. Br J Nutr 98, $860-867$.

69. Watras AC, Buchholz AC, Close RN, et al. (2007) The role of conjugated linoleic acid in reducing body fat and preventing holiday weight gain. Int J Obes 31, 481-487.

70. Norris LE, Collene AL, Asp ML, et al. (2009) Comparison of dietary conjugated linoleic acid with safflower oil on body composition in obese postmenopausal women with type 2 diabetes mellitus. Am J Clin Nutr 90, 468-476.

71. Zhao WS, Zhai JJ, Wang YH, et al. (2009) Conjugated linoleic acid supplementation enhances antihypertensive effect of ramipril in Chinese patients with obesity-related hypertension. Am J Hypertens 22, 680-686.

72. MacRedmond R, Singhera G, Attridge S, et al. (2010) Conjugated linoleic acid improves airway hyper-reactivity in overweight mild asthmatics. Clin Exp Allergy 40, 1071-1078.

73. Racine NM, Watras AC, Carrel AL, et al. (2010) Effect of conjugated linoleic acid on body fat accretion in overweight or obese children. Am J Clin Nutr 91, 1157-1164. 
74. Belury MA, Mahon A \& Banni S (2003) The conjugated linoleic acid (CLA) isomer, $t 10 c 12$-CLA, is inversely associated with changes in body weight and serum leptin in subjects with type 2 diabetes mellitus. J Nutr 133, 257S-260S.

75. Whigham LD, Watras AC \& Schoeller DA (2007) Efficacy of conjugated linoleic acid for reducing fat mass: a metaanalysis in humans. Am J Clin Nutr 85, 1203-1211.

76. Goedecke JH, Rae DE, Smuts CM, et al. (2009) Conjugated linoleic acid isomers. $t 10 c 12$ and $c 9 t 11$, are differentially incorporated into adipose tissue and skeletal muscle in humans. Lipids 44, 983-988.

77. Malpuech-Brugère C, Verboeket-van de Venne WP, Mensink RP, et al. (2004) Effects of two conjugated linoleic acid isomers on body fat mass in overweight humans. Obes Res 12, 591-598.

78. Risérus U, Vessby B, Arnlöv J, et al. (2004) Effects of cis-9,trans-11 conjugated linoleic acid supplementation on insulin sensitivity, lipid peroxidation, and proinflammatory markers in obese men. Am J Clin Nutr 80, 279-283.

79. Tricon S, Burdge GC, Kew S, et al. (2004) Opposing effects of cis-9,trans-11 and trans-10,cis-12 conjugated linoleic acid on blood lipids in healthy humans. Am J Clin Nutr 80, 614-620.

80. Desroches S, Chouinard PY, Galibois I, et al. (2005) Lack of effect of dietary conjugated linoleic acids naturally incorporated into butter on the lipid profile and body composition of overweight and obese men. Am J Clin Nutr 82, 309-319.

81. Plourde M, Jew S, Cunnane SC, et al. (2008) Conjugated linoleic acids: why the discrepancy between animal and human studies? Nutr Rev 66, 415-421.

82. World Health Organization (2009) Cardiovascular diseases (CVDs) Fact Sheet No. 317.http://www.who.int/ mediacentre/factsheets/fs317/en/index.html (accessed 12 January 2010)

83. Joint British Societies (2005) Joint British Societies' guidelines on prevention of cardiovascular disease in clinical practice. Heart 91, Suppl. 5, 1-52.

84. Keys A, Aravanis C, Blackburn HW, et al. (1966) Epidemiological studies related to coronary heart disease: characteristics of men aged 40-59 in seven countries. Acta Med Scand Suppl 460, 1-392.

85. Mitchell PL \& McLeod RS (2008) Conjugated linoleic acid and atherosclerosis: studies in animal models. Biochem Cell Biol 86, 293-301.

86. Lee KN, Kritchevsky D \& Pariza MW (1994) Conjugated linoleic acid and atherosclerosis in rabbits. Atherosclerosis 108, 19-25.

87. Kritchevsky D, Tepper SA, Wright S, et al. (2000) Influence of conjugated linoleic acid (CLA) on establishment and progression of atherosclerosis in rabbits. J Am Coll Nutr 19, $472 S-477 S$.

88. Kritchevsky D, Tepper SA, Wright S, et al. (2002) Influence of graded levels of conjugated linoleic acid (CLA) on experimental atherosclerosis in rabbits. Nutr Res 22, 1275-1279.

89. Kritchevsky D, Tepper SA, Wright S, et al. (2004) Conjugated linoleic acid isomer effects in atherosclerosis: growth and regression of lesions. Lipids 39, 611-616.

90. Nicolosi RJ, Rogers EJ, Kritchevsky D, et al. (1997) Dietary conjugated linoleic acid reduces plasma lipoproteins and early aortic atherosclerosis in hypercholesterolemic hamsters. Artery 22, 266-277.

91. Gavino VC, Gavino G, Leblanc MJ, et al. (2000) An isomeric mixture of conjugated linoleic acids but not pure cis-9 trans-11-octadecadienoic acid affects body weight gain and plasma lipids in hamsters. J Nutr 130, 27-29.
92. Toomey S, Harhen B, Roche HM, et al. (2006) Profound resolution of early atherosclerosis with conjugated linoleic acid. Atherosclerosis 187, 40-49.

93. Arbones-Mainar JM, Navarro MA, Guzman MA, et al. (2006) Selective effect of conjugated linoleic acid isomers on atherosclerotic lesion development in apolipoprotein $\mathrm{E}$ knockout mice. Atherosclerosis 189, 318-327.

94. Lock AL, Horne CAM, Bauman DE, et al. (2005) Butter naturally enriched in conjugated linoleic acid and vaccenic acid alters tissue fatty acids and improves the plasma lipoprotein profile in cholesterol-fed hamsters. J Nutr 135, 1934-1939.

95. Valeille K, Férézou J, Amsler G, et al. (2005) A cis-9, trans-11-conjugated linoleic acid-rich oil reduces the outcome of atherogenic process in hyperlipidemic hamster. Am J Physiol Heart Circ Physiol 289, 652-659.

96. Faulconnier Y, Roy A, Ferlay A, et al. (2006) Effect of dietary supply of butters rich either in trans-10-181 or in trans-11181 plus cis-9 trans-11-182 on rabbit adipose tissue and liver lipogenic activities. Br J Nutr 96, 461-468.

97. Valeille K, Ferezou J, Parquet M, et al. (2006) The natural concentration of the conjugated linoleic acid cis-9,trans11 , in milk fat has antiatherogenic effects in hyperlipidemic hamsters. J Nutr 136, 1305-1310.

98. Franczyk-Żarów M, Kostogrys RB, Szymczyk B, et al. (2008) Functional effects of eggs, naturally enriched with conjugated linoleic acid, on the blood lipid profile, development of atherosclerosis and composition of atherosclerotic plaque in apolipoprotein $\mathrm{E}$ and low-density lipoprotein receptor double-knockout mice (apoE/LDLR ${ }^{-/-}$). BrJ Nutr 99, 49-58.

99. House RL, Cassady JP, Eisen EJ, et al. (2005) Conjugated linoleic acid evokes de-lipidation through the regulation of genes controlling lipid metabolism in adipose and liver tissue. Obes Rev 6, 247-258.

100. Benito P, Nelson GJ, Kelley DS, et al. (2001) The effect of conjugated linoleic acid on plasma lipoproteins and tissue fatty acid composition in humans. Lipids 36, 229-236.

101. Risérus U, Berglund L \& Vessby B (2001) Conjugated linoleic acid (CLA) reduced abdominal adipose tissue in obese middle-aged men with signs of the metabolic syndrome: a randomised controlled trial. Int J Obes Relat Metab Disord 25, 1129-1135.

102. Naumann E, Carpentier YA, Saebo A, et al. (2006) Cis-9 trans-11 and trans-10, cis-12 conjugated linoleic acid (CLA) do not affect the plasma lipoprotein profile in moderately overweight subjects with LDL phenotype $\mathrm{B}$. Atherosclerosis 188, 167-174.

103. Raff M, Tholstrup T, Basu S, et al. (2008) A diet rich in conjugated linoleic acid and butter increases lipid peroxidation but does not affect atherosclerotic, inflammatory, or diabetic risk markers in healthy young men. J Nutr $\mathbf{1 3 8}$, 509-514.

104. Turpeinen AM, Ylönen N, von Willebrand E, et al. (2008) Immunological and metabolic effects of cis-9 trans-11conjugated linoleic acid in subjects with birch pollen allergy. Br J Nutr 100, 112-119.

105. Engberink MF, Geleijnse JM, Wanders AJ, et al. (2011) The effect of conjugated linoleic acid, a natural trans fat from milk and meat, on human blood pressure: results from a randomized crossover feeding study. J Hum Hypertens (epublication ahead of print version 27 January 2011).

106. Noone EJ, Roche HM, Nugent AP, et al. (2002) The effect of dietary supplementation using isomeric blends of conjugated linoleic acid on lipid metabolism in healthy human subjects. Br J Nutr $\mathbf{8 8}, 243-251$.

107. Moloney F, Yeow TP, Mullen A, et al. (2004) Conjugated linoleic acid supplementation, insulin sensitivity, and 
lipoprotein metabolism in patients with type 2 diabetes mellitus. Am J Clin Nutr 80, 887-895.

108. Ridker PM, Stampfer MJ \& Rifai N (2001) Novel risk factors for systemic atherosclerosis: a comparison of C-reactive protein, fibrinogen, homocysteine, lipoprotein(a), and standard cholesterol screening as predictors of peripheral arterial disease. JAMA 285, 2481-2485.

109. Lewington S, Whitlock G, Clarke R, et al. (2007) Blood cholesterol and vascular mortality by age, sex, and blood pressure: a meta-analysis of individual data from 61 prospective studies with 55000 vascular deaths. Lancet 370, 1829-1839.

110. Sofi F, Buccioni A, Cesari F, et al. (2009) Effects of a dairy product (pecorino cheese) naturally rich in cis-9 trans-11 conjugated linoleic acid on lipid, inflammatory and haemorheological variables: a dietary intervention study. Nutr Metab Cardiovasc Dis 20, 117-124.

111. Lichtenstein AH, Ausman LM, Jalbert SM, et al. (1999) Effects of different forms of dietary hydrogenated fats on serum lipoprotein cholesterol levels. $N$ Engl J Med 340, $1933-1940$.

112. Willett WC, Stampfer MJ, Manson JE, et al. (1993) Intake of trans fatty acids and risk of coronary heart disease among women. Lancet 341, 581-585.

113. Mozaffarian D, Katan MB, Ascherio A, et al. (2006) Trans fatty acids and cardiovascular disease. $N$ Engl J Med 354, $1601-1613$

114. Chardigny JM, Destaillats F, Malpuech-Brugère C, et al. (2008) Do trans fatty acids from industrially produced sources and from natural sources have the same effect on cardiovascular disease risk factors in healthy subjects? Results of the trans Fatty Acids Collaboration (TRANSFACT) study. Am J Clin Nutr 87, 558-566.

115. Mensink RP \& Nestel P (2009) Trans fatty acids and cardiovascular risk markers: does the source matter? Curr Opin Lipidol 20, 1-2.

116. Mensink RP (2005) Metabolic and health effects of isomeric fatty acids. Curr Opin Lipidol 16, 27-30.

117. Turpeinen AM, Mutanen M, Aro A, et al. (2002) Bioconversion of vaccenic acid to conjugated linoleic acid in humans. Am J Clin Nutr 76, 504-510.

118. Libby P, Ridker PM \& Hansson GK (2009) Inflammation in atherosclerosis: from pathophysiology to practice. $\mathrm{J} \mathrm{Am}$ Coll Cardiol 54, 2129-2138.

119. Gade W, Schmit J, Collins M, et al. (2010) Beyond obesity: the diagnosis and pathophysiology of metabolic syndrome. Clin Lab Sci 23, 51-61.

120. Yu Y, Correll PH \& Vanden Heuvel JP (2002) Conjugated linoleic acid decreases production of pro-inflammatory products in macrophages: evidence for a PPAR $\gamma$-dependent mechanism. Biochim Biophys Acta 1581, 89-99.

121. Jaudszus A, Foerster M, Kroegel C, et al. (2005) Cis-9,trans11-CLA exerts anti-inflammatory effects in human bronchial epithelial cells and eosinophils: comparison to trans-10,cis12-CLA and to linoleic acid. Biochim Biophys Acta 1737, $111-118$.

122. Loscher CE, Draper E, Leavy O, et al. (2005) Conjugated linoleic acid suppresses NF- $\mathrm{KB}$ activation and IL-12 production in dendritic cells through ERK-mediated IL-10 induction. J Immunol 175, 4990-4998.

123. Reynolds CM, Loscher CE, Moloney AP, et al. (2008) Cis-9 trans-11-conjugated linoleic acid but not its precursor trans-vaccenic acid attenuate inflammatory markers in the human colonic epithelial cell line Caco-2. Br J Nutr 100, 13-17.

124. Stachowska E, Dolegowska B, Dziedziejko V, et al. (2009) Prostaglandin $\mathrm{E}_{2}\left(\mathrm{PGE}_{2}\right)$ and thromboxane A2 (TXA2) synthesis is regulated by conjugated linoleic acids (CLA) in human macrophages. J Physiol Pharmacol 60, 77-85.

125. Changhua L, Jindong Y, Defa L, et al. (2005) Conjugated linoleic acid attenuates the production and gene expression of proinflammatory cytokines in weaned pigs challenged with lipopolysaccharide. J Nutr 135, 239-244.

126. Butz DE, Li G, Huebner SM, et al. (2007) A mechanistic approach to understanding conjugated linoleic acid's role in inflammation using murine models of rheumatoid arthritis. Am J Physiol Regul Integr Comp Physiol 293, R669-R676.

127. Noto A, Zahradka P, Ryz NR, et al. (2007) Dietary conjugated linoleic acid preserves pancreatic function and reduces inflammatory markers in obese, insulin-resistant rats. Metabolism 56, 142-151.

128. LaRosa PC, Miner J, Xia Y, et al. (2006) Trans-10 cis-12 conjugated linoleic acid causes inflammation and delipidation of white adipose tissue in mice: a microarray and histological analysis. Physiol Genomics 27, 282-294.

129. Poirier H, Shapiro JS, Kim RJ, et al. (2006) Nutritional supplementation with trans-10 cis-12-conjugated linoleic acid induces inflammation of white adipose tissue. Diabetes 55, 1634-1641.

130. Smedman A, Basu S, Jovinge S, et al. (2005) Conjugated linoleic acid increased C-reactive protein in human subjects. Br J Nutr 94, 791-795.

131. Tholstrup T, Raff M, Straarup EM, et al. (2008) An oil mixture with trans-10 cis-12 conjugated linoleic acid increases markers of inflammation and in vivo lipid peroxidation compared with cis-9, trans-11 conjugated linoleic acid in postmenopausal women. J Nutr 138, 1445-1451.

132. MacRedmond R, Singhera G, Attridge S, et al. (2010) Conjugated linoleic acid improves airway hyper-reactivity in overweight mild asthmatics. Clin Exp Allergy 40, 1071-1078.

133. Stickford JL, Mickleborough TD, Fly AD, et al. (2011) Conjugated linoleic acid's lack of attenuation of hyperpneainduced bronchoconstriction in asthmatic individuals in the short term. Int J Sport Nutr Exerc Metab 21, 40-47.

134. Tricon S, Burdge GC, Kew S, et al. (2004) Effects of cis-9, trans-11 and trans-10,cis-12 conjugated linoleic acid on immune cell function in healthy humans. Am J Clin Nutr 80, 1626-1633.

135. Ramakers JD, Plat J, Sebedio JL, et al. (2005) Effects of the individual isomers cis-9,trans-11 vs trans-10, cis-12 of conjugated linoleic acid (CLA) on inflammation parameters in moderately overweight subjects with LDL-phenotype B. Lipids 40, 909-918.

136. Risérus U, Basu S, Jovinge S, et al. (2002) Supplementation with conjugated linoleic acid causes isomer-dependent oxidative stress and elevated C-reactive protein: a potential link to fatty acid-induced insulin resistance. Circulation 106, 1925-1929.

137. Kelley DS, Taylor PC, Rudolph IL, et al. (2000) Dietary conjugated linoleic acid did not alter immune status in young healthy women. Lipids 35, 1065-1071.

138. Nugent AP, Roche HM, Noone EJ, et al. (2005) The effects of conjugated linoleic acid supplementation on immune function in healthy volunteers. Eur J Clin Nutr 59, 742-750.

139. Song HJ, Grant I, Rotondo D, et al. (2005) Effect of CLA supplementation on immune function in young healthy volunteers. Eur J Clin Nutr 59, 508-517.

140. Mullen A, Moloney F, Nugent AP, et al. (2007) Conjugated linoleic acid supplementation reduces peripheral blood mononuclear cell interleukin-2 production in healthy middle-aged males. J Nutr Biochem 18, 658-666.

141. Taylor CG \& Zahradka P (2004) Dietary conjugated linoleic acid and insulin sensitivity and resistance in rodent models. Am J Clin Nutr 79, 1164S-1168S. 
142. Belury MA (2002) Dietary conjugated linoleic acid in health: physiological effects and mechanisms of action. Annu Rev Nutr 22, 505-531.

143. Roche HM, Noone E, Sewter C, et al. (2002) Isomer-dependent metabolic effects of conjugated linoleic acid: insights from molecular markers sterol regulatory element-binding protein-1c and LXR $\alpha$. Diabetes 51, 2037-2044.

144. Moloney F, Toomey S, Noone E, et al. (2007) Antidiabetic effects of cis-9 trans-11-conjugated linoleic acid may be mediated via anti-inflammatory effects in white adipose tissue. Diabetes 56, 574-582.

145. Houseknecht KL, Vanden Heuvel JP, Moya-Camarena SY, et al. (1998) Dietary conjugated linoleic acid normalizes impaired glucose tolerance in the Zucker diabetic fatty fa/fa rat. Biochem Biophys Res Commun 244, 678-682.

146. Ryder JW, Portocarrero CP, Song XM, et al. (2001) Isomerspecific antidiabetic properties of conjugated linoleic acid Improved glucose tolerance, skeletal muscle insulin action, and UCP-2 gene expression. Diabetes 50, 1149-1157.

147. Tsuboyama-Kasaoka N, Takahashi M, Tanemura K, et al. (2000) Conjugated linoleic acid supplementation reduces adipose tissue by apoptosis and develops lipodystrophy in mice. Diabetes 49, 1534-1542.

148. Halade GV, Rahman MM \& Fernandes G (2009) Effect of CLA isomers and their mixture on aging $\mathrm{C} 57 \mathrm{Bl} / 6 \mathrm{~J}$ mice. Eur J Nutr 48, 409-418.

149. Halade GV, Rahman MM \& Fernandes G (2009) Differential effects of conjugated linoleic acid isomers in insulin-resistant female C57Bl/6J mice. J Nutr Biochem 21, 332-337.

150. de Roos B, Rucklidge G, Reid M, et al. (2005) Divergent mechanisms of cis 9 trans 11 -and trans 10 , cis 12 -conjugated linoleic acid affecting insulin resistance and inflammation in apolipoprotein $\mathrm{E}$ knockout mice: a proteomics approach. FASEB J 19, 1746-1748.

151. de Roos B \& McArdle HJ (2008) Proteomics as a tool for the modelling of biological processes and biomarker development in nutrition research. Br J Nutr 99, S66-S71.

152. Risérus U, Smedman A, Basu S, et al. (2004) Metabolic effects of conjugated linoleic acid in humans: the Swedish experience. Am J Clin Nutr 79, 1146S-1148S.

153. Ahren B, Mari A, Fyfe CL, et al. (2009) Effects of conjugated linoleic acid plus $n-3$ polyunsaturated fatty acids on insulin secretion and estimated insulin sensitivity in men. EurJ Clin Nutr 63, 778-786.

154. Tarnopolsky M, Zimmer A, Paikin J, et al. (2007) Creatine monohydrate and conjugated linoleic acid improve strength and body composition following resistance exercise in older adults. PLoS One 2, e991.

155. Eyjolfson V, Spriet LL \& Dyck DJ (2004) Conjugated linoleic acid improves insulin sensitivity in young, sedentary humans. Med Sci Sports Exerc 36, 814-820.

156. Risérus U (2006) Trans fatty acids and insulin resistance. Atheroscler Suppl 7, 37-39.

157. Alberti KG, Eckel RH, Grundy SM, et al. (2009) Harmonizing the metabolic syndrome: a joint interim statement of the International Diabetes Federation Task Force on Epidemiology and Prevention; National Heart, Lung, and Blood Institute; American Heart Association; World Heart Federation; International Atherosclerosis Society; and International Association for the Study of Obesity. Circulation 120, 1640-1645.

158. Prentice A, Schoenmakers I, Laskey MA, et al. (2006) Nutrition and bone growth and development. Proc Nutr Soc 65 , $348-360$.
159. National Osteoporosis Society (2009) National Osteoporosis Society http://www.nos.org.uk/NetCommunity/ (accessed 20 October 2009).

160. Lanham-New SA (2008) Importance of calcium, vitamin D and vitamin $\mathrm{K}$ for osteoporosis prevention and treatment. Proc Nutr Soc 67, 163-176.

161. Roy BD \& Antolic AM (2009) Conjugated linoleic acid (CLA) and bone health: a review. Curr Topics Nutraceutical Res 7, 27-36.

162. Hur SJ \& Park Y (2007) Effect of conjugated linoleic acid on bone formation and rheumatoid arthritis. Eur J Pharmacol 568, 16-24.

163. Watkins BA \& Seifert MF (2000) Conjugated linoleic acid and bone biology. J Am Coll Nutr 19, 478S-486S.

164. Kelly O \& Cashman KD (2004) The effect of conjugated linoleic acid on calcium absorption and bone metabolism and composition in adult ovariectomised rats. Prostaglandins Leukot Essent Fatty Acids 71, 295-301.

165. Kelly O, Cusack S, Jewell C, et al. (2003) The effect of polyunsaturated fatty acids, including conjugated linoleic acid, on calcium absorption and bone metabolism and composition in young growing rats. Br J Nutr 90, 743-750.

166. Li Y \& Watkins BA (1998) Conjugated linoleic acids alter bone fatty acid composition and reduce ex vivo prostaglandin $\mathrm{E}_{2}$ biosynthesis in rats fed $n-6$ or $n-3$ fatty acids. Lipids 33, 417-425.

167. Li Y, Seifert MF, Ney DM, et al. (1999) Dietary conjugated linoleic acids alter serum IGF-I and IGF binding protein concentrations and reduce bone formation in rats fed ( $n$-6) or (n-3) fatty acids. J Bone Miner Res 14, 1153-1162.

168. Watkins BA, Shen CL, McMurtry JP, et al. (1997) Dietary lipids modulate bone prostaglandin $\mathrm{E}_{2}$ production, insulin-like growth factor-I concentration and formation rate in chicks. $J$ Nutr 127, 1084-1091.

169. Jewell C \& Cashman KD (2003) The effect of conjugated linoleic acid and medium-chain fatty acids on transepithelial calcium transport in human intestinal-like Caco-2 cells. Br J Nutr 89, 639-647.

170. Park Y, Pariza MW \& Park Y (2008) Cosupplementation of dietary calcium and conjugated linoleic acid (CLA) improves bone mass in mice. J Food Sci 73, C556-C560.

171. Weiler H, Austin S, Fitzpatrick-Wong S, et al. (2004) Conjugated linoleic acid reduces parathyroid hormone in health and in polycystic kidney disease in rats. Am J Clin Nutr 79, 1186S-1189S.

172. Weiler HA, Fitzpatrick S \& Fitzpatrick-Wong SC (2008) Dietary conjugated linoleic acid in the cis-9 trans-11 isoform reduces parathyroid hormone in male, but not female, rats. J Nutr Biochem 19, 762-769.

173. Brownbill RA, Petrosian M \& Ilich JZ (2005) Association between dietary conjugated linoleic acid and bone mineral density in postmenopausal women. J Am Coll Nutr 24, 177-181.

174. Doyle L, Jewell C, Mullen A, et al. (2005) Effect of dietary supplementation with conjugated linoleic acid on markers of calcium and bone metabolism in healthy adult men. Eur J Clin Nutr 59, 432-440.

175. Kreider RB, Ferreira MP, Greenwood M, et al. (2002) Effects of conjugated linoleic acid supplementation during resistance training on body composition, bone density, strength, and selected hematological markers. $J$ Strength Cond Res 16, 325-334.

176. Kant AK \& Graubard BI (2006) Secular trends in patterns of self-reported food consumption of adult Americans: NHANES 1971-1975 to NHANES 1999-2002. Am J Clin Nutr 84, 1215-1223. 